\title{
COVID-19 and its Therapeutics: Special Emphasis on Mesenchymal Stem Cells Based Therapy
}

\author{
Yogesh Kumar Verma ${ }^{1} \cdot$ Ranjan Verma ${ }^{1}$ - Nishant Tyagi ${ }^{1}$ - Amanpreet Behl ${ }^{1} \cdot$ Subodh Kumar ${ }^{1}$. \\ Gurudutta U. Gangenahalli ${ }^{1}$ (I)
}

Published online: 12 September 2020

(C) Springer Science+Business Media, LLC, part of Springer Nature 2020

\begin{abstract}
The novel virus, Severe Acute Respiratory Syndrome Coronavirus-2 (SARS-CoV-2) caused the Corona Virus Disease-2019 (COVID-19) outbreak in Wuhan, Hubei province of China. This virus disseminated rapidly and reached to an unprecedented pandemic proportion in more than 213 nations with a large number of fatalities. The hypersecretion of pro-inflammatory cytokines is the main cause of mortality and morbidity due to COVID-19, therefore strategies that avert the cytokine storm may play a crucial role in abating the severity of COVID-19. This review highlights the minute details of SARS-CoV-2, its genomic organization, genomic variations within structural and non-structural proteins and viral progression mechanism in human beings. The approaches like antiviral strategies are discussed, including drugs that obstruct viral propagation and suppress the pro-inflammatory cytokines. This compilation emphasizes Mesenchymal Stem Cells (MSCs) based therapy alone or in combination with other therapeutics as an attractive curative approach for COVID-19 pandemic. The MSCs and its secretome, including antimicrobial peptides (AMPs) have various capabilities, for instance, immunomodulation, regeneration, antimicrobial properties, potential for attenuating the cytokine storm and bare minimum chances of being infected with SARS-CoV-2 virus. The immunomodulatory property of MSCs affects inflammatory state and regulates immune response during SARS-CoV-2 infection. However, as of now, there is no WHO-approved MSCs based therapy for the treatment of COVID-19 infection.
\end{abstract}

Keywords SARS-CoV-2 $\cdot$ Cytokine storm $\cdot$ Repurposed drugs $\cdot$ MSCs transplantation $\cdot$ Antimicrobial peptides

\begin{tabular}{|c|c|c|c|}
\hline \multicolumn{2}{|l|}{ Abbreviations } & MCP1 & Monocyte chemoattractant protein-1 \\
\hline SARS & Severe Acute Respiratory Syndrome & MIP1A & Macrophage inflammatory protein $1 \mathrm{~A}$ \\
\hline MERS & Middle East Respiratory Syndrome & $\mathrm{TNF} \alpha$ & Tumor necrosis factor-alpha \\
\hline \multirow[t]{2}{*}{ SARS-CoV-2 } & Severe Acute Respiratory & ARDS & Acute respiratory distress syndrome \\
\hline & Syndrome Coronavirus & ORF & Open reading frame \\
\hline \multirow{3}{*}{$\begin{array}{l}\text { MSCs } \\
\text { BM- MSCs } \\
\text { AMPS }\end{array}$} & Mesenchymal Stem Cells & UTR & Untranslated region \\
\hline & Bone marrow Mesenchymal Stem Cells & HA & Hemagglutinin \\
\hline & Antimicrobial peptides & DPP4 & Dipeptidyl peptidase 4 \\
\hline & Interleukin & ACE-2 & Angiotensin-converting enzyme 2 \\
\hline GSCF & Granulocyte colony-stimulating factor & CyA & Cyclophilin A \\
\hline \multirow[t]{2}{*}{ IP10 } & Interferon gamma-induced protein 10 & TMPRSS2 & Transmembrane serine protease 2 \\
\hline & & RdRp & RNA-dependent RNA polymerase \\
\hline \multirow{2}{*}{\multicolumn{2}{|c|}{$\begin{array}{l}\text { This article belongs to the Topical Collection: Special Issue on COVID- } \\
19 \text { Pandemic and Stem Cells } \\
\text { Guest Editor: Mariusz Z. Ratajczak }\end{array}$}} & 3CLpro & Coronavirus main protease \\
\hline & & NF- $\mathrm{kB}$ & Nuclear Factor kappa-B \\
\hline \multirow{2}{*}{\multicolumn{2}{|c|}{$\begin{array}{l}\text { Yogesh Kumar Verma, Ranjan Verma, Nishant Tyagi, Amanpreet Behl } \\
\text { and Subodh Kumar contributed equally to this work. }\end{array}$}} & CTD & Carboxy terminal domain \\
\hline & & NTD & N-terminal domain \\
\hline \multirow{3}{*}{\multicolumn{2}{|c|}{$\begin{array}{l}\triangle \text { Gurudutta U. Gangenahalli } \\
\text { gugdutta@rediffmail.com }\end{array}$}} & SIRS & Systemic inflammatory response syndrome \\
\hline & & MODS & Multiple organ dysfunction syndromes \\
\hline & & PAMP & Pathogen-associated molecular pattern \\
\hline Division of $\mathrm{St}$ & m Cell \& Gene Therapy Research, Institute of Nuclear & TLRs & Toll-like receptors \\
\hline Medicine \& & ed Sciences (INMAS), Brig. S.K. Mazumdar Road, & IFN & Interferon \\
\hline
\end{tabular}




$\begin{array}{ll}\text { IRF } & \text { IFN regulatory factor } \\ \text { IFNAR } & \text { Interferon- } \alpha / \beta \text { receptor } \\ \text { JAK } & \text { Janus kinase } \\ \text { TYK } & \text { Tyrosine-protein kinase } \\ \text { STAT } & \begin{array}{l}\text { Signal transducer and activator of } \\ \text { transcription }\end{array} \\ & \text { Antigen-presenting cells } \\ \text { APCs } & \text { Cytokine release syndrome } \\ \text { CRS } & \text { Vesicular Stomatitis Virus } \\ \text { VSV } & \text { Vascular endothelial growth factor } \\ \text { VEFG } & \text { Hepatocyte growth factor } \\ \text { HGF } & \text { Lipoxin A4 } \\ \text { LXA4 } & \text { Regulated on activation, normal T cell } \\ \text { RANTES } & \text { expressed and secreted } \\ & \text { Prostaglandin E2 } \\ \text { PGE2 } & \text { Transforming growth factor-beta 1 } \\ \text { TGF- } \beta 1 & \text { Indoleamine-pyrrole 2,3-dioxygenase } \\ \text { IDO } & \text { Nitric oxide } \\ \text { NO } & \text { Granulocyte-macrophage } \\ \text { GM-CSF } & \text { colony-stimulating factor } \\ \text { GSK } & \text { Glycogen synthase kinase } \\ \text { COX2 } & \text { Cyclooxygenase-2 } \\ \text { HLA-G5 } & \text { Human leukocyte antigen-G molecules } \\ \text { MHC } & \text { Major histocompatibility complex } \\ \text { PD-L1 } & \text { Programmed death-ligand 1 } \\ \text { CD } & \text { Cluster of differentiation } \\ \text { hBD } & \text { human } \beta \text {-defensin } \\ & \end{array}$

\section{Introduction}

The term coronavirus (Latin: corona, crown) is coined due to presence of spikes glycoproteins on the surface that gives this virus a crown-like appearance. Coronaviruses belong to the family Coronaviridae and the order Nidovirales [1], broadly distributed in humans and other mammals, having a large positive-sense RNA encapsulated within a protein coat. Coronaviruses majorly affect animals and display zoonotic transmission from animals to humans. They have been classified into four groups, namely, alpha $(\alpha)$, beta $(\beta)$, gamma $(\gamma)$ and delta $(\delta)$, causing illness ranging from mild fever and cold to severe diseases, like the Middle East Respiratory Syndrome (MERS) and Severe Acute Respiratory Syndrome (SARS). Most of the human coronaviruses cause mild infection but in the past two decades coronaviruses of beta family viz. Severe Acute Respiratory Syndrome Coronavirus (SARS-CoV) and the Middle East Respiratory Syndrome Coronavirus (MERS$\mathrm{CoV}$ ), have resulted in more than 10,000 cumulative cases and had a fatality rate of $10 \%$ and $37 \%$ respectively $[2,3]$. Recently, a new member of the beta group of coronaviruses, SARS-CoV-2 has been identified, which has caused a pandemic disease (COVID-19) across the globe. Similar to SARS-CoV, the SARS-CoV-2 also affects the lower respiratory system to cause viral pneumonia. Furthermore, many reports suggest a disturbance in gastrointestinal system, heart, kidney, liver and central nervous system that ultimately lead to multiple organ failure. The SARS-CoV-2 virus stimulates a profusion of cytokines such as IL-2, IL-6, IL-7, G-SCF, IP10, MCP1, MIP1A, and TNF $\alpha$. This inflammatory response is known as cytokines storm. It is followed by edema, dysfunction of air exchange, acute respiratory distress syndrome, acute cardiac injury and secondary infections. Sometimes cytokines storm becomes extraordinary, resulting in multiple organ failure and death $[4,5]$. Therefore strategies that circumvent the cytokine storm may play a pivotal role in the COVID-19 treatment. MSCs possess immunomodulatory properties, secrete various AMPs and have a minimum probability of being contaminated with SARS-CoV-2 virus due to absence of ACE-2 receptor [4]. In this review, we have concisely discussed COVID-19 infection, its genome organization, structural and non-structural proteins, and all the information that would make readers cognizant about this viral disease. We have also reviewed the immunomodulatory and antimicrobial properties of MSCs to combat this viral pandemic.

\section{Comparative Analysis of Commencement and Dispersion of Coronaviruses}

In the year 2003, people of Guangdong province of China were infected by a virus that led to SARS. It was found to be a member of the beta coronaviruses and named SARS$\mathrm{CoV}$. The infected population exhibited pneumonia-like symptoms with a diffused alveolar injury that causes acute respiratory distress syndrome (ARDS). This disease disseminated all around the globe in a short span of time and infected more than 8000 people and resulted in 800 deaths with $10 \%$ mortality rate. After a decade, in the year 2012, another member of the coronavirus family was identified and its zone of infection was majorly confined to the Arabian Peninsula and consequently, the virus was named as MERS-CoV. This outbreak had 2260 confirmed cases and 803 reported deaths. It targets the upper respiratory tract and causes severe respiratory distress [1]. At present, the whole world is experiencing an outbreak due to a novel strain of coronavirus named as SARSCoV-2 and the resultant disease called as COVID-19. This outbreak was commenced in Wuhan, Hubei province of China, on December 2019, from seafood and live animal shopping market as shopping and feeding of animals like bats, frogs and snakes are permissible in China. The exact role of bats in the zoonotic origin of SARS-CoV-2 is not clear but scientists isolated SARS-CoV-2 from the infected patients for genomic sequencing and the subsequent studies suggested that this virus has $96.2 \%$ sequence similarity to bat $\mathrm{CoV}$ RaTG13 genome sequence reproductive number $\left(\mathrm{R}_{0}\right)$ of 
SARS-CoV-2 virus is $2.2-2.5\}$. This revealed that SARS$\mathrm{CoV}-2$ is most closely related to the viruses originated from bats $[6,7]$. Its progression is detrimental to respiratory organs that lead to their malfunction. From Wuhan, this pandemic spilled over to more than 213 countries having 22,341,273 confirmed cases and 785,103 deaths till August 19th, 2020 [8]. The virus transmission took place from bats to the human community. Due to close contact with aerosols generated during coughing and sneezing, the disease spread rapidly among humans. The SARS-CoV-2 remains stable for many hours to days, depending upon the medium, for example, in aerosols it will survive up to $3 \mathrm{~h}$, on copper for $4 \mathrm{~h}$, and on cardboard up to $24 \mathrm{~h}$, whereas on plastic and stainless steel it remains alive for 2-3 days [9]. On comparing SARS-CoV-2 with other viruses, such as influenza virus, SARS-CoV, MERS-CoV, it shows maximum mortality (Table 1).

\section{Genomic Organization of SARS-CoV-2}

The comprehensive erudition about virus genetics and phenotypic traits play a key role in developing drugs and vaccine against SARS-CoV-2. It is a single-stranded positivesense RNA, enveloping the largest genome (approximately $30 \mathrm{~kb}$ ) among all the RNA viruses [10]. The orientation of genomic RNA of $\beta$-coronaviridae is from 5 '-to-3'direction; it is interspersed with 6 open reading frames (ORF) and structural protein-coding genes. Most of the virion replicase genes are encoded by the $5^{\prime}$ end and it covers about twothird (266 to $21,552 \mathrm{bp}$ ) of the SARS-CoV-2 genome (Fig. 1a). The genome includes two overlapping ORF, named as ORF1a (13442-to-12,468 bp) and ORF1b (13407-to-16,236 bp), followed by helicase (16237-to18,039 bp), 3'-to-5' exonuclease (18040-to-19,620 bp), endoRNase (19,621 to $20,658 \mathrm{bp})$ and o-ribosomal methyltransferase (20,659 to $21,552 \mathrm{bp})$ genes [11]. These genes are translated by a ribosome upstream of the ORF1a stop codon. Translation of both ORFs in the cytoplasm of infected cells results in synthesis of two polyproteins, ppla and pplab. These proteins are processed by two viral proteinases to yield 16 functional non-structural proteins (nsps) and the orientation of these nsps is from $5^{\prime}$ to $3^{\prime}$ end of the RNA genome. The nsps are the components of the membrane-anchored replication-transcription complex. Among all the nsps, the largest non-structural protein (nsp) of SARS-COV-2 is nsp3 that acts as a multifunctional protein. It is an interferon antagonist (because of papain-like protease domain) having deubiquitinating deISGylation activity that could be involved in inhibition of interferon responses [12]. The genes encoding for structural protein are present at the 3' end of the RNA genome and the order of the genes is, spike protein (S) (21563-to-25,384 bp), envelope protein (E) (26245-to-26,472 bp), structural membrane glycoprotein protein (M) (26523-to-27,191 bp), ORF6 protein (27202-to-27,387 bp), ORF7a (27394-to-27,759 bp), ORF7b (27756-to-27,557 bp), ORF 8 (27894-to-

Table 1 Comparison of the viruses belonging to the coronavirus family. M, Membrane Glycoprotein; E, Envelope protein; S, Spike glycoprotein; ACE-2, Angiotensin-converting enzyme 2

\begin{tabular}{|c|c|c|c|c|c|c|}
\hline Virus & Origin & Size & Outer protein & Cognate receptor & Affected area & $\begin{array}{l}\text { Number of } \\
\text { Cases }\end{array}$ \\
\hline $\begin{array}{l}\text { Influenza } \\
\text { (flu) }\end{array}$ & $\begin{array}{l}\text { Enveloped, single-strand } \\
\text { RNA (ssRNA) isolated } \\
\text { in 1933. The core nu- } \\
\text { cleoprotein is used to } \\
\text { distinguish A, B, and C } \\
\text { types of human influ- } \\
\text { enza. }\end{array}$ & $\begin{array}{l}\text { About } \\
80-120 \mathrm{~nm} \text {. } \\
\text { Elliptical in } \\
\text { shape. }\end{array}$ & $\begin{array}{l}\text { Abundant surface } \\
\text { protein is } \\
\text { hemagglutinin } \\
\text { (HA) and neur- } \\
\text { aminidase }(\mathrm{N}) \text {. }\end{array}$ & $\begin{array}{l}\text { As the outer protein is } \\
\text { hemagglutinin, it will bind } \\
\text { to any cell receptor } \\
\text { containing sialic acid, thus } \\
\text { have a multi-step entry. }\end{array}$ & $\begin{array}{l}\text { All over Asia, } \\
\text { highly } \\
\text { contagious. }\end{array}$ & 10 million \\
\hline SARS-CoV & $\begin{array}{l}\text { Identified in } 2003 \text { as an } \\
\text { animal virus, } \\
\text { transmitted through } \\
\text { bats. }\end{array}$ & $\begin{array}{l}\text { Ranging from } 80 \\
\text { to } 90 \mathrm{~nm} .\end{array}$ & $\begin{array}{l}\text { The viral envelope } \\
\text { consists of a lipid } \\
\text { bilayer with M, E, } \\
\text { and S proteins. }\end{array}$ & $\begin{array}{l}\text { The spike protein in the virus } \\
\text { binds to the cellular } \\
\text { transmembrane ACE2 } \\
\text { receptor. }\end{array}$ & $\begin{array}{l}\text { A large } \\
\text { number of } \\
\text { countries. }\end{array}$ & 8000 \\
\hline MERS-CoV & $\begin{array}{l}\text { Discovered in } 2012 \text { in } \\
\text { humans. Phylogenetic } \\
\text { studies suggest bats as } \\
\text { origin; camel and then } \\
\text { humans as a host. }\end{array}$ & $\begin{array}{l}\text { In between } 80 \\
\text { and } 90 \mathrm{~nm} .\end{array}$ & $\begin{array}{l}\text { Spikes that form a } \\
\text { crown structure } \\
\text { with outer proteins } \\
\mathrm{M} \text { and } \mathrm{E} \text {. }\end{array}$ & $\begin{array}{l}\text { Spike protein binds to } \\
\text { dipeptidyl peptidase } 4 \\
\text { (DPP4) as a functional re- } \\
\text { ceptor. }\end{array}$ & $\begin{array}{l}\text { Mostly in } \\
\text { Arabian } \\
\text { Peninsula. }\end{array}$ & 2260 \\
\hline $\begin{array}{l}\text { SARS-CoV-2 } \\
\text { (COVI- } \\
\text { D-19) }\end{array}$ & $\begin{array}{l}\text { From Wuhan, China. } \\
\text { Most possible origin is } \\
\text { bat. }\end{array}$ & $\begin{array}{l}\text { About } \\
\text { 80-160 nm. }\end{array}$ & $\begin{array}{l}\text { The viral envelope } \\
\text { consists of a lipid } \\
\text { bilayer with M, E, } \\
\text { and S proteins. }\end{array}$ & $\begin{array}{l}\text { ACE-2 receptor and cellular } \\
\text { serine protease TMPRSS2 } \\
\text { is essential for entry. }\end{array}$ & $\begin{array}{l}213 \text { countries } \\
\text { and } \\
\text { territories } \\
\text { around the } \\
\text { world } \\
\text { (Ongoing). }\end{array}$ & $\begin{array}{l}22,341,273 \\
\text { confirmed } \\
\text { cases till } \\
\text { August 19th } \\
2020 \\
\text { (Ongoing). }\end{array}$ \\
\hline
\end{tabular}



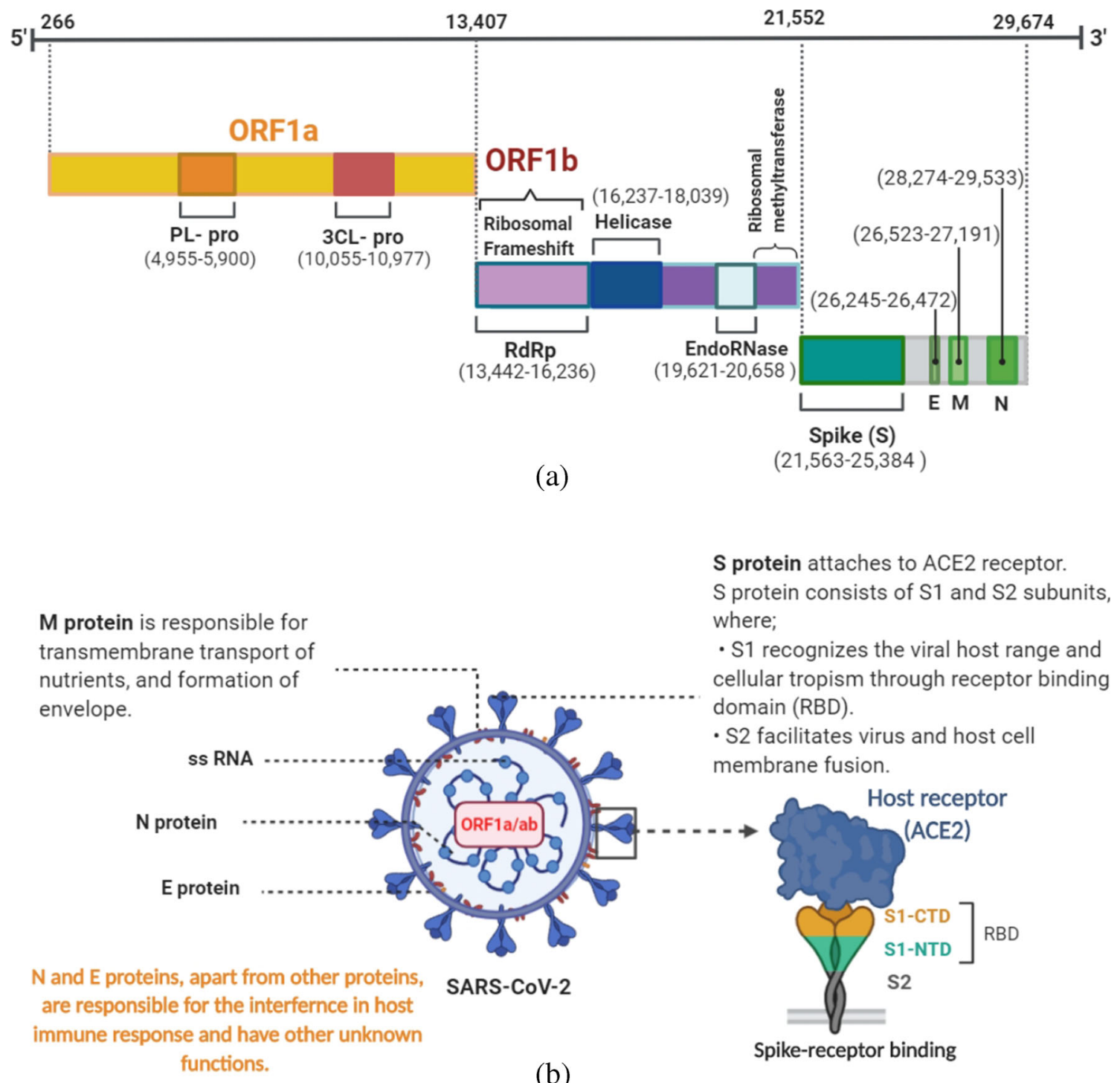

Fig. 1 Genome organization and structure of SARS-CoV-2. a SARS$\mathrm{CoV}-2$ genome contains ORF $1 \mathrm{a} / \mathrm{b}$ (yellow and violet box respectively) which encodes genes like PL-pro, 3CL-pro, RNA- dependent RNA polymerase, helicase and endonuclease. The green box represents the size (in base pair) of spike protein, membrane protein and nucleocapsid

protein. b Illustrates the SARS-CoV-2 structure, function of different membrane proteins and the mechanism of spike-receptor binding to ACE-2 receptor of host. CTD, carboxy-terminal domain; NTD, Nterminal domain; PL-pro, papain-like protease; 3CL-pro, 3CL-protease; RdRp, RNA- dependent RNA polymerase

28,259 bp), nucleocapsid (N) (28274-29,533 bp), ORF10 (29558-to-29,674 bp), followed by 3'UTR region [11].

\section{Genomic Variations in SARS-CoV-2}

The viruses of the Coronaviridae family have acquired some variations in their genetics and pathogenicity. The SARS-CoV (79\%) and MERS-CoV (50\%) [13] are genetically similar to SARS-CoV-2. Both 5' UTR and 3' UTR are involved in various processes like inter- and intra-molecular interactions, binding of viral and cellular proteins. $\mathrm{Pblab}$ gene is the first ORF present at the $5^{\prime}$ end, encoding nsps of size around $1.9 \mathrm{kbp}$ in SARS-CoV-2, 2.9kbp in SARS-CoV and $30 \mathrm{kbp}$ in MERS-CoV. Some variations were also spotted in the spike protein sequence at the $3^{\prime}$ ends. Spike protein consists of 1273 amino acids, 21,493 amino acid, and 1270 amino acids in SARS-CoV-2, SARS-CoV, and MERS-CoV, respectively.

\section{Structural Proteins of SARS-CoV-2}

\section{Spike Glycoprotein (S Protein)}

The SARS-CoV-2 infection takes place when S protein interacts with ACE- 2 receptor of the host cell. The size of S protein is about 20 to $40 \mathrm{~nm}$ and it consists of two functional subunits S1 and S2 (Fig. 1b), bounded by non-covalent perfusion 
conformation. S1 subunit is responsible for the binding of SARS-CoV-2 with the host cell while S2 subunit mediates viral fusion with the host cell membrane. This is followed by delivery of viral genome into the cytoplasm. The S2 subunit also forms complex surface projections surrounding the periphery of the SARS-CoV-2 particles [6, 14].

\section{Envelope Protein (E)}

This is a 76 amino acids long, small integral membrane protein with a short hydrophilic chain at amino-terminus followed by a long hydrophobic region and a hydrophilic carboxy-terminus. It contains at least one $\alpha$-helix transmembrane domain. During viral replication, it is present in high concentration inside the infected host cell to participate in viral assembly, budding, envelope formation and virulence [15-17].

\section{Nucleocapsid Protein (N)}

Nucleocapsid protein of SARS-CoV-2 functions in enveloping the entire virus RNA genome. It helps in interaction of the genome with other structural proteins for virus particle assembly and release into the host. The well-known mechanism of viral spread into the host is still unknown but interaction of $\mathrm{N}$ protein and cyclophilin A (CyA) might provide a new hint for the SARS-CoV-2 infection pathway in human cells [18]. Sequence alignment indicates that a segment of $\mathrm{N}$ protein is homologous to human immunodeficiency virus- 1 capsid protein with identity of $25.1 \%$ and a similarity of $36.7 \%$. The studies indicate that CyA is important in infection of SARS-CoV-2 and this could be a novel target for COVID-19 therapy [19].

\section{Membrane Glycoprotein (M)}

The gene for membrane glycoproteins of $\beta$-coronavirus is located at the $3^{\prime}$ end of genomic RNA. The $\mathrm{M}$ and E proteins have a vital role in the assembly of virus inside the host cells. Especially, M protein promotes assembly of viral genome through its interaction with ribonucleoprotein and $\mathrm{S}$ protein facilitates networking of $\mathrm{M}-\mathrm{M}, \mathrm{M}-\mathrm{E}, \mathrm{M}-\mathrm{N}, \mathrm{M}-\mathrm{S}, \mathrm{M}-\mathrm{RNA}$ and N-RNA. These interactions are mediated by palmitin. Finally, the assembled packets of virion are moved out of the host cell via secretory pathways $[17,19]$.

\section{Non-structural Proteins (Nsps)}

The genes of nsps are located at the $5^{\prime}$ end of the viral genome, encoding various nsps which help in replication and transcription of viral genome within the host cell. The viral protease is one of the nsps which activates functional polypeptide by an extensive proteolytic cleavage. For example, 3CL-pro cleaves the polypeptide at 11 conserved sites containing Leu, Gln, Ser, Ala, and Gly amino acids. This process is initiated by the enzyme's autolytic cleavage from pp1a and pplab, this cleavage pattern remains conserved in the SARS-CoV-2 [20].

\section{Mechanism of Viral Progression}

The virus specifically recognizes the host's ACE-2 receptor and transmembrane protease serine 2 protein (TMPRSS2) by its spike protein. The ACE- 2 receptors are immensely present on the surface of many human cells, especially the alveolar type II cells and capillary endothelium. However, ACE-2 receptors are consistently absent in bone marrow, lymph nodes, thymus, spleen, and immune cell such as $T$ and B lymphocytes, and macrophages. The viral genome also contains genes for other nsps like RNA dependent RNA polymerase (RdRp), papain-like protease (PLpro) and coronavirus cysteine protease (3CLpro), also known as the main protease. Once the virus has entered the cell, it releases its genomic RNA and hijacks the protein synthesis mechanism of host cell. Replication and transcription of RNA genome of the virus are catalysed by RdRp. Its genome is located at the C-terminal part of nsp12 [21]. RdRp is a core catalytic subunit for the production of the positive and negative-strand RNA, thus it can serve as an important target for design of diagnostic RT-PCR probes and antiviral drugs [15]. The positive-strand RNA is translated into polyproteins. These polyproteins are than cleaved by PLpro and 3CLpro to form effector proteins. Further, deubiquitination of interferon factor 3 and NF-kB by PLpro (behaves like a deubiquitinase) suppresses the host immunity. The synthesized negative-strand RNA is utilized to produce more number of the viral genome.

\section{COVID-19 Manifestation}

The common sign and symptoms of COVID-19 are fever, fatigue, dry cough, and shortness of breath. Some patients may also experience headache, runny nose, sore throat, or diarrhea. Initially, these symptoms are mild, the severity begins gradually with an increase in infection that culminates into systemic inflammatory response syndrome (SIRS) and multiple organ dysfunction syndrome (MODS) due to hyperimmune response also known as cytokines storm [22]. Various procedures are employed for the direct detection of COVID-19, these are based on either identifying the viral genome through RT-PCR or antibody detection (Fig. 2). Nearly one in six people who contract COVID-19 are very sick and has difficulty in breathing. Several studies have suggested that the 
(1) Nasopharyngeal swab Cotton swab is inserted into min nostril to absorb secretions.
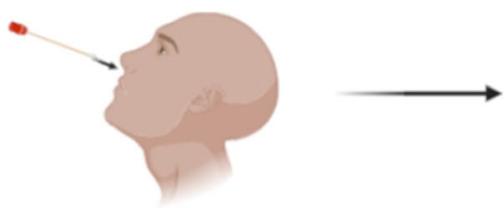

RT- PCR

$\sim 1 \mathrm{~h}$ per primer set

Purified RNA is reverse transcribed to CDNA and amplified by PCR.

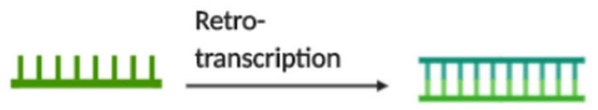

(3) RNA extraction

Purified RNA is extracted from

deactivated virus.
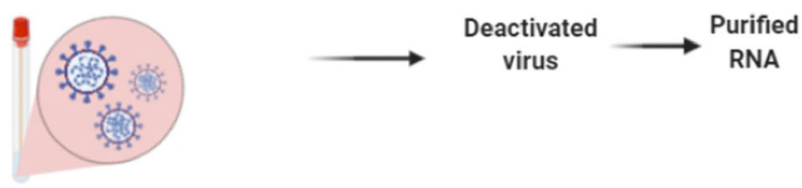

(5) Test results real-time

Positive SARS-CoV-2 patients cross the threshold line within 40.00 cycles.

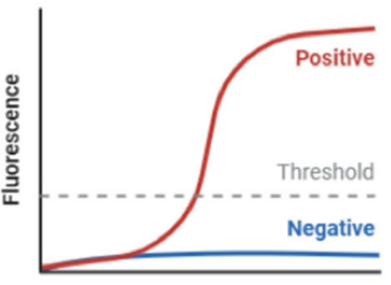

Copies per reaction (Ct)

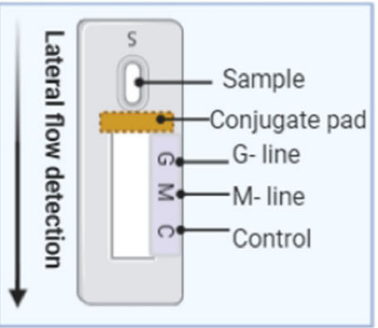

Lateral flow detection (LFD)
(1) Sample loading

Add a drop of blood or serum in sample well (S).

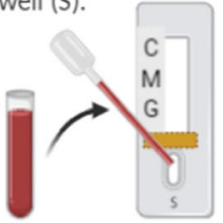

(2) Antibody-antigen recognition site

Antibodies bind on gold COVID-19 conjugate pad.

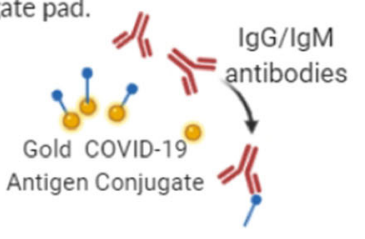

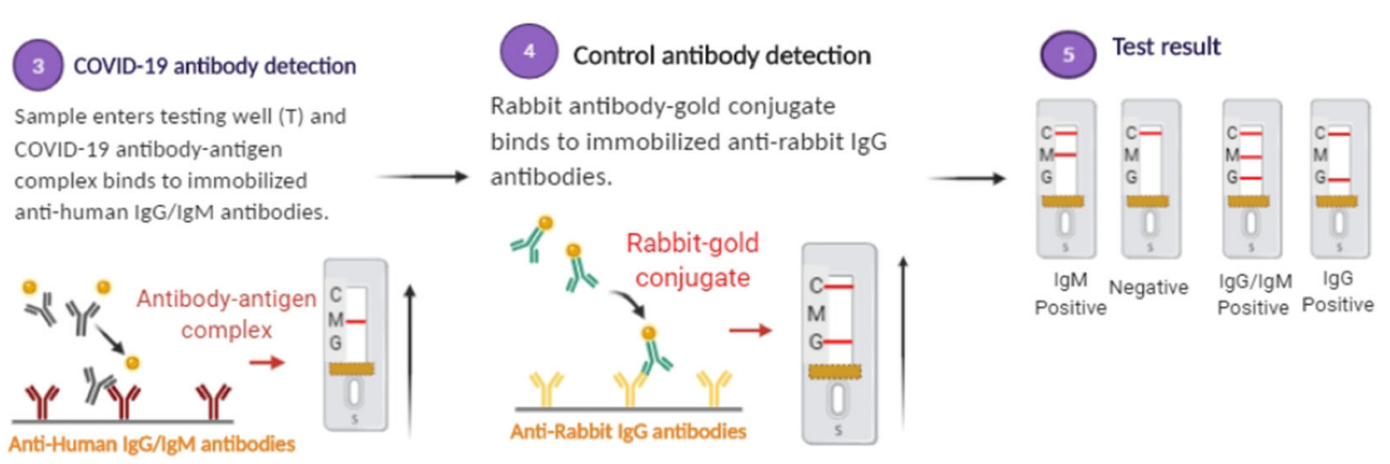

(b)

Fig. 2 Methods used for COVID-19 detection. a Diagnostic test for direct detection of COVID-19, this identifies the viral RNA through RT-PCR. b Serological testing of the disease through lateral flow detection (LFD). C; control, G-line, M-line; IgM antibodies, IgG antibodies

probability of COVID-19 prognosis is worse in patients older than 60 years and constitute more than $73 \%$ of total recorded deaths. Patients with comorbidities like high blood pressure, heart surgeries, and diabetes, also have a higher probability of getting infected [23-26].

\section{Immune Response during SARS-CoV-2 Infection}

The innate immune response against viral infection majorly depends on interferon (IFN) type I protein and its 
downstream signalling. During an antiviral response, the viral RNA is served as a pathogen-associated molecular pattern molecule (PAMP) and recognized by endosomal RNA receptor (TLR-3 and TLR-7) and cytosolic RNA sensor RIG-I/MDA5. This activates NF-kB and interferon regulatory transcription factor-3 (IRF-3), which translocate into the nucleus. Here they induce expression of IFN type I along with some pro-inflammatory cytokines, this initial response constructs a first-line defence against the viral entry. Furthermore, with the help of Interferon- $\alpha / \beta$ receptor (IFNAR), IFN type I activates JAK-STAT pathway. In downstream signalling, JAK1 and TYK2 kinases activate STAT1 and STAT2, subsequently forming a complex with IRF 9 [27]. This complex translocates inside the nucleus and activates the IFN-stimulated genes. The IFN type I response is essential for viral suppression, however during SARS$\mathrm{CoV}-2$ infection, this response is suppressed. The active viral replication further causes delayed IFN type I response, this heralds an influx of neutrophils and macrophages (a major source of pro-inflammatory cytokines). Sometimes patients are asymptomatic due to early delayed response of the innate immunity [28].

The Th1 immune response has a decisive role during the adaptive response. The activity of $\mathrm{T}$ cells is regulated by antigen-presenting cells (APCs) via engendering the cytokine environment. The overall adaptive response by $\mathrm{T}$ helper cells activates the humoral immune retaliation, which acts as an immune shield along with neutralizing antibody. Simultaneously, the cytotoxic T cells start clearance of viral cells. A strong T cell response was noted in case of SARSCoV-2 infection in correlation with higher amount of neutralizing antibodies and Th2 cytokines such as IL-4, IL-5 and IL$10[28,29]$.

\section{Cytokine Release Syndrome (CRS)}

The CRS is caused by hypersecretion of a large number of proinflammatory cytokines (peptides) such as IL-2, IL-6, IL-7, G-CSF, IP-10 and TNF- $\alpha[4,27,30]$. It is commonly observed in immune-related diseases or immune therapies such as chimeric antigen receptor $\mathrm{T}$ cell therapy (CAR-T), organ transplantation, sepsis, etc. The proinflammatory peptides enhance the vascular permeability, as a result, enormous amount of blood and fluid accumulate in lungs, especially in alveoli, that leads to respiratory failure. A similar condition is also observed in COVID-19 patients (Fig. 3). The CRS actuates viral sepsis and aggrandizes production of the proinflammatory cytokines causing pneumonia and acute respiratory disease syndrome (ARDS). In severe cases, respiratory and multiple organ failure is the main cause of COVID-19 related fatalities (Fig. 3b) [22, 31].

\section{Approaches to Combat COVID-19}

Even after rigorous studies performed on SARS-CoV-2, there is no potential therapeutic agent available against this virus. Many therapies have been recommended for its treatment, for instance, the use of ACE-2 and TMPRSS2 inhibitors, plasma containing antibodies, drugs that obstruct the advancement of viral transmission and infection. Several existing antiviral agents are also being repurposed as potential therapeutic agents against SARS-CoV-2. Here we have discussed all the treatments being tested for COVID-19.

\section{Blocking the Interaction between ACE-2 Receptor and Spike Protein Via Anti-ACE-2 Antibody}

Both SARS-CoV and SARS-CoV-2 display S protein, this binds to the host cells via cell surface protein receptor ACE2. It is the sole receptor used by SARS-CoV-2 while other receptors like, aminopeptidase $\mathrm{N}$ and dipeptidyl peptidase, are exploited by many coronaviruses for their entry into the host. The study by Hoffmann et al. [32] showed that antiACE-2 antibody could block the entry of Vesicular Stomatitis Virus pseudotype (VSV) expressing the S protein of SARS-CoV-2.

\section{Inhibition of TMPRSS2 Activity}

For the invasion of SARS-CoV-2, S protein needs to be cleaved at two distinct positions by serine protease TMPRSS2, a process called as S protein priming. It is essential for interaction between the host cellular membrane and coronavirus [33]. Camostat mesilate is an inhibitor of TMPRSS2, the treatment of SARS-CoV-2 infected lung cells with this inhibitor prevents the viral entry into the cell [32].

\section{By Introducing a Soluble Form of ACE-2}

If an excess of ACE- 2 is introduced in the soluble form, it competitively binds to $\mathrm{S}$ protein of SARS-CoV-2. This approach exerts dual function, firstly it neutralizes viral cells present in the host, secondly, it rescues the cellular activity of ACE-2 and protects lungs from injury [34].

\section{Anti-Viral Approaches}

The advancement of SARS-CoV-2 into the host cell is facilitated by both structural and non-structural proteins but, the main machinery for viral replication and progression is encoded by the genes located at the $5^{\prime}$ end of the genome. After virus entry, transcription is mediated by nsps genes present in ORF1a and ORF1b, which express enzymes and proteins required for viral proliferation. The viral progression can be restrained if an antagonist of these genes can be developed 


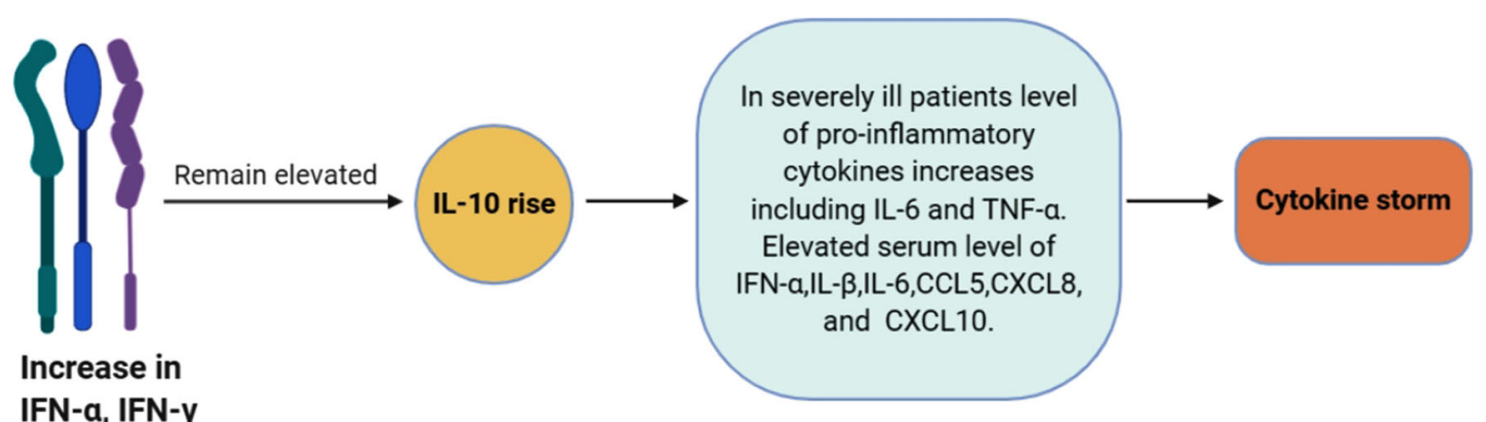
and TNF

(a)

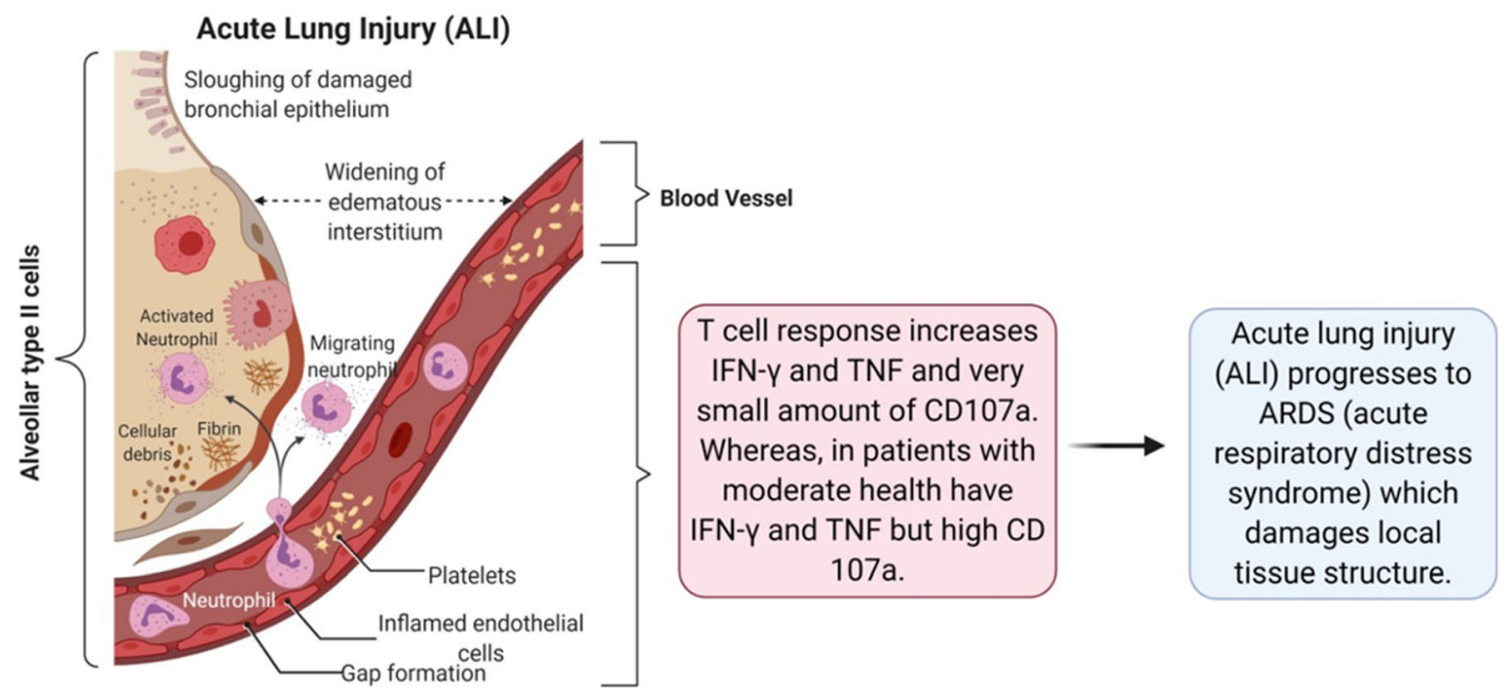

CD8+ Tcells and natural killer(NK)cells are contributor of cytokinesto inflammatory response. This results in; 1. Increased extravascular pressure, and intracellular $\mathrm{Ca}^{2+}$ 2. Endothelial dysfunction and,

3. Decreased tissue perfusion.

Fig. 3 Mechanism of CRS in critically ill COVID-19 patients. a In severe case, increase in IFN- $\alpha$, IFN- $\gamma$ and TNF receptor gives rise to uncontrolled pro- and anti-inflammatory response. b The SARS-CoV-2 infects the alveolar type II cells, enhances permeability of these cells, and stimulates macrophages, neutrophils and other components of innate and

\section{(b)}

adaptive immunity. This further impedes the IFN type I response and causes a rapid influx of neutrophils, monocytes/macrophages resulting in hypersecretion of cytokines, ultimately leading to ARDS and multiple organs failure. IFN; interferon, TNF; tumor necrosis factor
Table 2 Drugs and their anti-viral mechanism against viral proteins

\begin{tabular}{lll}
\hline S. No. & Antiviral drugs & Mechanism of action \\
\hline 1 & Cathepsin L inhibitors & Block viral entry or inhibits in-vitro infection. \\
2 & Amiodarone & Inhibits virus infection at a post-endosomal level. \\
3 & Tetra-O-galloyl-beta-D-glucose & Blocks SARS-CoV-2 or SARS-CoV pseudovirus entry. \\
4 & Luteolin & Blocks SARS-CoV-2 or SARS-CoV pseudovirus entry. \\
5 & VE607 & Restrains S protein-ACE-2 mediated viral entry. \\
6 & siSC2-5 & Targets the S protein and ORF1b. \\
7 & Hexamethylene amiloride & Hinders ion channel activity and viral replication. \\
\hline
\end{tabular}


(Table 2). Some anti-viral drugs have also been shown to block post-endosomal infection by inhibiting the endosome level in host cells and thereby inhibiting viral replication $[35,36]$.

\section{Repurposed Drugs}

Many anti-viral drugs are being repurposed for COVID-19 treatment. Drugs like Remdesivir, Chloroquine, Lopinavir and Ritonavir (Table 3) are clinically employed antivirals. They impede viral replication, premature termination and prevent viral infection by increasing $\mathrm{pH}$ of endosome.

\section{Emerging Mesenchymal Stem Cells (MSCs) Therapy against COVID-19}

In the past few decades, scientists have started showing tremendous interest in MSCs based therapies in a wide variety of biomedical disciplines due to their immunomodulatory, antimicrobial and paracrine properties including secretion of extracellular vesicles, regulatory miRNA, and multiple bioactive proteins. These cells, also known as multipotent stromal cells due to their ability to differentiate into a limited number of cell types, are characterized by fibroblast-like morphology. MSCs can develop into cells of the three different germ layers[71, 72]. Besides bone marrow (BM), MSCs can be extracted from a wide number of sources like adipose tissues, fetal liver, cord blood, mobilized peripheral blood, fetal lung, placenta, umbilical cord, dental pulp, synovial membrane, endometrium, trabecular and compact bone [74-77]. Utilization of different methods for their isolation, expansion and characterization, influence the post-MSCstransplantation clinical outcome. To overcome this problem, Mesenchymal and Tissue Stem Cell Committee of the International Society for Cellular Therapy, has proposed three golden standards for characterizing human MSCs. First, MSCs is an adherent cell line and having plastic-adherent nature. These cells attach to the culture plate in standard culture conditions. Second, during flow cytometry analysis, it has been observed that $>95 \%$ MSCs population express CD105 \{known as endoglin and originally recognized by the monoclonal antibody (MAb SH2)\}, CD73 (known as ecto-5'-nucleotidase and originally recognized by the MAb SH3 and SH4) and CD 90 (also known as Thy-1) cell surface markers. Moreover, MSCs lack the expression of CD45 (leukocyte antigen), CD34 (hematopoietic progenitors and endothelial cells marker), CD14 (monocytes antigen) or CD11b (macrophages marker), CD79a or CD19 (B cells antigen) and HLA class II markers. Finally, one special property that is unique to MSCs is the ability to differentiate into osteoblasts (stained with Alizarin Red or von Kossa staining), adipocytes (identified using Oil Red O) and chondroblasts (coloured with Alcian blue) under the standard culture conditions [78, 79]. As these cells are in surplus with anti-microbial activity and immunomodulatory effects, MSCs can be served as an attractive target for cell-based therapy of COVID-19. Additionally, MSCs lack the ACE-2 receptor, which is an important entry point for SARS-CoV-2 into a human host [4].

\section{The Restorative Power of MSCs}

MSCs are currently investigated in various animal models and clinical trials for their immunotherapeutic potential. As COVID-19 pandemic was initiated in China, most of the studies are performed in association with Chinese institute [80-82] but as this pandemic escalated to other parts of the world, recently some nations, for instance, United State of America, Jordon, Brazil, and Spain, have started exploring the immunomodulatory potential of MSCs in clinical trials (Table 4) [83, 84, 86]. Zikuan Leng and co-workers [4] have performed a study on SARS-CoV-2 infected patients to investigate the potential of MSCs transplantation. A total of seven patients were assessed for 14 days. After intravenous injection of MSCs, all the clinical after-effects, such as changes in immune function and inflammatory level were recorded periodically. It was observed that this treatment significantly enhanced the immune level and pulmonary function without adverse effects. Among those seven patients, one was critically serious but discharged within 10 days. During the treatment, MSCs reduced rapid surge of macrophages and activated a high number of regulatory dendritic cells in SARS-CoV-2 infected tissue. MSCs based therapy has shown promising results in the treatment of ARDS in lipopolysaccharide (E. coli derived) induced sepsis animal model. MSCs attenuated the incoming neutrophils in lungs and reduced the level of TNF $\alpha$ (a proinflammatory cytokine) in immune cells residing in lungs through IL-10 secretion. Furthermore, MSCs treatment repaired the alveolar- epithelial barrier that is disrupted in ARDS and regenerated alveolar type II cells. This also prevented apoptosis of endothelial cells by producing keratinocyte growth factor (KGF), vascular endothelial growth factor (VEFG), and hepatocyte growth factor (HGF). Alongside pro-resolving mediator lipoxin A4 (LXA4), MSCs decreased the ongoing inflammation and pulmonary edema. Due to MSCs immunosuppressant properties, inflammation, and the level of pro-inflammatory cytokines in the patient's serum decreased dramatically [87]. These reports suggest that MSCs could be one of the best alternatives to suppress the CRS in pulmonary region. So, by harnessing the regenerative potential and immunomodulatory properties, MSCs based therapy would likely to serve as a crucial antidote for combating the COVID-19 pandemic. 
Table 3 List of agents that are being repurposed as therapeutic agents against SARS-CoV-2

\begin{tabular}{lll}
\hline Drug & Indications & Mechanism of action \\
\hline Chloroquine & $\begin{array}{l}\text { 1. Malarial parasite infection and } \\
\text { amebicide. }\end{array}$ & $\begin{array}{c}\text { Elevates endosomal pH and interferes } \\
\text { with ACE-2 glycosylation. }\end{array}$ \\
& $\begin{array}{l}\text { 2. Rheumatoid arthritis. } \\
\text { Ren }\end{array}$ &
\end{tabular}

Possible action on SARS-CoV-2

$\begin{array}{ll}\text { Remdesivir (RDV) } & \text { 1. Ebola } \\ & \text { 2. SARS-CoV } \\ & \text { 3. MERS-CoV }\end{array}$

Hydroxychloroquine 1. Malaria

2. Rheumatoid arthritis

3. Discoid, or systemic lupus and erythematosus.

Ritonavir 1. Human immunodeficiency virus (HIV)

2. SARS-CoV-2

\section{Chlorpheniramine 1. A histamine $\mathrm{H} 1$ antagonist used in allergic reactions, hay fever, rhinitis, urticaria, and asthma. Also used in veterinary applications. One of the most widely used classical antihistaminic. \\ Lopinavir-Ritonavir 1. Usually prescribed with HIV medication to boost immunity of a patient.}

Oseltamivir Influenza viruses A (including
pandemic H1N1) and B.

Lopinavir

1. Approved drug combination for HIV.

$\begin{array}{ll}\text { Rifampin } & \begin{array}{l}\text { 1. A semisynthetic antibiotic produced } \\ \text { from Streptomyces mediterranei. It has } \\ \text { a broad antibacterial spectrum, } \\ \text { including activity against several forms } \\ \text { of Mycobacterium. }\end{array} \\ \text { Baricitinib } & \text { 1. Rheumatoid arthritis }\end{array}$

Darunavir

1. HIV
A nucleotide analogue that blocks viral nucleotide synthesis to stop viral replication. The likely mechanism of action is delayed RNA chain termination.

It is a disease-modifying anti-rheumatic drug. It regulates activity of immune system, which may be overactive in some conditions.

It prevents cleavage of the gag-pol polyprotein, which results in non-infectious, immature viral particles.

It is a potent inhibitor of cytochrome P450, and CYP3A4 isoenzyme, found in the intestinal tract and liver.

It is a type II ligand that perfectly fits into the CYP3A4 active site cavity and irreversibly binds to heme iron via thiazole nitrogen, which decreases redox potential of protein and averts its reduction with the redox partner, cytochrome $\mathrm{P} 450$ reductase.

It can bind to the histamine $\mathrm{H} 1$ receptor. This blocks the action of endogenous histamine, which leads to temporary relief from the negative symptoms of histamine.

Both Lopinavir and Ritonavir belong to a class of drugs known as HIV protease inhibitors. Ritonavir boosts the levels of Lopinavir.

1. It is known to block receptors of SARS- CoV-2.

2. It has an immune-modulating activity and targets the endosome/ACE-2 receptor [37, 38].

It can inhibit replication of a wide variety of coronaviruses by blocking the RNA dependent RNA polymerase required for replication [39-41].

It can modify underlying disease process, rather than simply treating the symptoms [42, 43].

It can inhibit the viral protease and activates the nuclear receptor subfamily-1 [44, 45].

It works by blocking the action of histamine, a substance in the body that causes allergic reactions likely to reduce inflammation. [46-49].

The randomized trial found that Lopinavir-Ritonavir treatment added to standard supportive care was not associated with clinical improvement or mortality in seriously ill patients with COVID-19 infection as compared to standard care alone [50, 51].

It inhibits activity of the viral neuraminidase enzyme found on the surface of virus, which prevents budding from the host cell, viral replication, and infectivity.

It has been recommended by WHO for people at high risk of infection before or after exposure to pandemic influenza. May reduce COVID-19 transmission [52].

It is currently under investigation in combination with Ritonavir for the treatment of COVID-19 treatment [53-55].

It inhibits DNA-dependent RNA polymerase, leading to suppression of RNA synthesis and cell death.

It suppresses initiation of RNA synthesis. It is bactericidal and acts on both intracellular and extracellular organisms. Under trail for COVID-19 [56-59].

Blocks action of JAK $1 / 2$, and disrupts activation of downstream signalling molecules and pro-inflammatory mediators.
It inhibits tyrosine-protein kinase JAK1, JAK2, JAK3, protein-tyrosine kinase 2-beta, which can interfere with inflammatory process $[60,61]$. 
Table 3 (continued)

\begin{tabular}{|c|c|c|c|}
\hline Drug & Indications & Mechanism of action & Possible action on SARS-CoV-2 \\
\hline & 2. SARS-CoV-2 (under clinical trials) & $\begin{array}{l}\text { It is an HIV protease inhibitor, prevents } \\
\text { HIV replication by binding to the } \\
\text { enzyme, stops the dimerization and } \\
\text { catalytic activity of HIV-1 protease. In } \\
\text { particular, it inhibits cleavage of HIV } \\
\text { encoded Gag-Pol proteins in cells that } \\
\text { have been infected with the virus, } \\
\text { halting formation of mature virus par- } \\
\text { ticles. Primary active site amino acids } \\
\text { (Asp-29 and Asp-30) on the protease } \\
\text { likely contribute to its potency and ef- } \\
\text { ficacy against resistant variants of } \\
\text { HIV-1. }\end{array}$ & $\begin{array}{l}\text { It is being studied as a possible treatment } \\
\text { for SARS-CoV-2 due to in vitro evi- } \\
\text { dence supporting its ability to combat } \\
\text { this infection. Clinical trials are under- } \\
\text { way and are expected to conclude by } \\
\text { August } 2020 \text { [62]. }\end{array}$ \\
\hline $\begin{array}{l}\text { Favipiravir (also } \\
\text { known as } \\
\text { Avifavir) }\end{array}$ & $\begin{array}{l}\text { 1. Influenza A virus (strain A/Silky } \\
\text { Chicken/Hong Kong/SF189/2001 } \\
\text { H5N1 genotype A) }\end{array}$ & $\begin{array}{l}\text { The active Favipiravir-RTP selectively } \\
\text { inhibits RNA polymerase and prevents } \\
\text { replication of viral genome. }\end{array}$ & $\begin{array}{l}\text { It has been investigated for treatment of } \\
\text { life-threatening pathogens such as } \\
\text { Ebola virus, Lassa virus, and now } \\
\text { SARS-CoV-2. It is recently approved } \\
\text { by the Russian government for } \\
\text { COVID-19 treatment [63-65]. }\end{array}$ \\
\hline Galidesivir & $\begin{array}{l}\text { 1. Ebola } \\
\text { 2. Marburg } \\
\text { 3. Yellow Fever } \\
\text { 4. Zika viruses }\end{array}$ & $\begin{array}{l}\text { It works by inhibiting the nucleotides } \\
\text { binding site on viral RNA polymerase, } \\
\text { leading to a structural change in the } \\
\text { enzyme due to altered electrostatic } \\
\text { interactions. Disruption of viral RNA } \\
\text { polymerase activity results in } \\
\text { premature termination of the } \\
\text { elongating RNA strand. }\end{array}$ & $\begin{array}{l}\text { It inhibits the "RNA-directed RNA } \\
\text { polymerase L" action [66]. }\end{array}$ \\
\hline Umifenovir & $\begin{array}{l}\text { 1. Herpes simplex virus } \\
\text { 2. Hepatitis B virus } \\
\text { 3. Hepatitis C Virus } \\
\text { 4. SARS-CoV-2 } \\
\text { 5. Zika virus } \\
\text { 6. Lassa mammarenavirus } \\
\text { 7. Chikungunya virus } \\
\text { 8. Coxsackievirus B5 } \\
\text { 9. Reovirus species } \\
\text { 10. Hantaan orthohantvirus } \\
\text { 11. Ebola virus }\end{array}$ & $\begin{array}{l}\text { It is considered as direct-acting antiviral } \\
\text { due to virucidal effects and a } \\
\text { host-targeting agent due to effects on } \\
\text { one or multiple stages of the viral life } \\
\text { cycle (e.g. attachment, internalization). } \\
\text { It targets the S protein and the ACE2 } \\
\text { receptor. }\end{array}$ & $\begin{array}{l}\text { It is being investigated as a potential } \\
\text { treatment and prophylactic agent for } \\
\text { COVID-19 in combination with both } \\
\text { currently available and investigational } \\
\text { HIV therapies [67-70]. }\end{array}$ \\
\hline Nitazoxanide & $\begin{array}{l}\text { 1. Anti-Helminthic } \\
\text { 2. Anti-Protozoal } \\
\text { 3. Viral infection-induced diarrhoea }\end{array}$ & $\begin{array}{l}\text { It induces lesions in cell membrane and } \\
\text { depolarizes mitochondrial membrane } \\
\text { by inhibiting quinone oxidoreductase } \\
\text { (NQO1), nitroreductase- } 1 \text { and protein } \\
\text { disulphide isomerase enzymes. }\end{array}$ & $\begin{array}{l}\text { A drug that may inhibit viral protein } \\
\text { expression [73]. }\end{array}$ \\
\hline
\end{tabular}

\section{MSCs Regulate the Cytokines Storm during Severe SARS-CoV-2 Infection}

MSCs have been reported to control the immune homeostasis, as these cells possess many immunomodulatory abilities [88]. MSCs modulate the adaptive and innate immune response by suppression of $\mathrm{T}$ cells, maturation of dendritic cells, reducing $\mathrm{B}$ cell activation and proliferation, inhibiting proliferation and cytotoxicity of NK cells, and promoting generation of regulatory $\mathrm{T}$ cells via soluble factors (paracrine) or cell-cell contact (juxtacrine) mechanism [88, 89]. MSCs exert both pro- and anti-inflammatory effects. Toll-like receptors (TLR, mainly
TLR3 and TLR4) present on MSCs dictate the fate of MSCs as pro-inflammatory or anti-inflammatory. TLR receptors present on MSCs are triggered by pathogen-associated molecular pattern (PAMP), like in RNA viruses [90]. TLR3 activation by a microbial molecule is associated with anti-inflammation. MSCs secrete chemokines like MIP- $1 \alpha$ and MIP- $1 \beta$, RANTES, CXCL9, CXCL10, and CXCL11 after activation of TLR4 by microbial molecules. These chemokines recruit lymphocytes at the sites of infection and further activate $T$ cells as inflammatory cytokines are present in low concentration. However, to weaken inflammatory response [90], MSCs switch to TLR3 activation leading to anti-inflammatory 
Table 4 List of MSCs based clinical trials performed in different countries for the treatment of COVID-19 [83-85]

\begin{tabular}{|c|c|c|c|c|c|}
\hline $\begin{array}{l}\text { Clinical Trial } \\
\text { number }\end{array}$ & Title & Study phase & Status & Responsible Party & Country \\
\hline NCT04299152 & $\begin{array}{l}\text { Stem cell educator therapy treat the viral } \\
\text { inflammation in COVID- } 19\end{array}$ & Phase 2 & Not yet recruiting & $\begin{array}{l}\text { Tianhe Stem Cell } \\
\text { Biotechnologies Inc. }\end{array}$ & $\begin{array}{l}\text { United States of } \\
\text { America }\end{array}$ \\
\hline NCT04355728 & $\begin{array}{l}\text { Umbilical cord-derived MSCs for COVID-19 } \\
\text { patients with acute respiratory distress } \\
\text { syndrome (ARDS). }\end{array}$ & $\begin{array}{l}\text { Phase } 1 \text { and Phase } \\
\quad 2\end{array}$ & $\begin{array}{l}\text { Active, not } \\
\text { recruiting }\end{array}$ & $\begin{array}{l}\text { Camillo Ricordi, } \\
\text { University of Miami }\end{array}$ & $\begin{array}{l}\text { Miami, Florida, } \\
\text { United States of } \\
\text { America }\end{array}$ \\
\hline NCT04313322 & $\begin{array}{l}\text { Treatment of COVID-19 patients using } \\
\text { Wharton's jelly MSCs. }\end{array}$ & Phase 1 & Recruiting & $\begin{array}{l}\text { Adeeb Al Zoubi, Stem } \\
\text { Cell Arabia, }\end{array}$ & Aman, Jordon \\
\hline NCT04315987 & $\begin{array}{l}\text { Exploratory clinical study to assess the } \\
\text { efficacy of NestaCel }{ }^{1} \text { MSCs to treat } \\
\text { patients with severe COVID-19 pneumo- } \\
\text { nia. }\end{array}$ & Phase 2 & Not yet recruiting & Azidus & São Paulo, Brazil \\
\hline NCT04302519 & $\begin{array}{l}\text { Clinical study of novel coronavirus induced } \\
\text { severe pneumonia treated by dental pulp } \\
\text { MSCs. }\end{array}$ & Early Phase 1 & Not yet recruiting & $\begin{array}{l}\text { CAR-T (Shanghai) } \\
\text { Biotechnology Co., } \\
\text { Ltd. }\end{array}$ & China \\
\hline NCT04288102 & $\begin{array}{l}\text { Treatment with human umbilical cord-derived } \\
\text { MSCs for severe coronavirus disease } 2019 \\
\text { (COVID-19). }\end{array}$ & Phase 2 & $\begin{array}{l}\text { Active, not } \\
\text { Recruiting }\end{array}$ & $\begin{array}{l}\text { Fu-Sheng Wang, } \\
\text { Beijing } 302 \text { Hospital }\end{array}$ & $\begin{array}{l}\text { Wuhan, Hubei, } \\
\text { China }\end{array}$ \\
\hline NCT04269525 & $\begin{array}{l}\text { Umbilical cord (UC)-derived MSCs treatment } \\
\text { for the 2019-novel Coronavirus (COV) } \\
\text { pneumonia. }\end{array}$ & Phase 2 & Recruiting & $\begin{array}{l}\text { ZhiYong Peng, } \\
\text { Zhongnan Hospital }\end{array}$ & $\begin{array}{l}\text { Wuhan, Hubei, } \\
\text { China }\end{array}$ \\
\hline NCT04276987 & $\begin{array}{l}\text { A pilot clinical study on inhalation of MSCs } \\
\text { exosomes treating severe novel } \\
\text { coronavirus pneumonia. }\end{array}$ & Phase 1 & $\begin{array}{l}\text { Enrolling by } \\
\text { invitation }\end{array}$ & Ruijin Hospital & Shanghai, China \\
\hline NCT04293692 & $\begin{array}{l}\text { Therapy for pneumonia patients infected by } \\
2019 \text { novel coronavirus }\end{array}$ & Not applicable & Withdrawn & $\begin{array}{l}\text { Puren hospital affiliated } \\
\text { to Wuhan University } \\
\text { of Science and } \\
\text { Technology }\end{array}$ & $\begin{array}{l}\text { Wuhan, Hubei, } \\
\text { China }\end{array}$ \\
\hline NCT04456361 & $\begin{array}{l}\text { Use of MSCs in acute respiratory distress } \\
\text { syndrome caused by COVID- } 19 \text {. }\end{array}$ & Early Phase 1 & $\begin{array}{l}\text { Active, not } \\
\text { recruiting }\end{array}$ & $\begin{array}{l}\text { Instituto de Medicina } \\
\text { Regenerativa }\end{array}$ & $\begin{array}{l}\text { Tijuana, Baja } \\
\text { California, } \\
\text { Mexico }\end{array}$ \\
\hline NCT04366323 & $\begin{array}{l}\text { Phase I/II clinical trial to evaluate the safety } \\
\text { and efficacy of allogenic adipose } \\
\text { tissue-derived MSCs expanded in patients } \\
\text { with severe COVID-19 pneumonia. }\end{array}$ & $\begin{array}{l}\text { Phase } 1 \\
\text { Phase } 2\end{array}$ & Recruiting & $\begin{array}{l}\text { Hospital Universitario } \\
\text { de Jerez de la } \\
\text { Frontera }\end{array}$ & Spain \\
\hline
\end{tabular}

response during a severe immune retaliation caused by a high level of inflammatory cytokines. Similar kind of cytokines storm has been observed in severely infected COVID-19 patients. In COVID-19, hypersecretion of pro-inflammatory cytokines such as IL-2, IL-6, IL-7, G-SCF, IP10, MCP1, MIP1A, and TNF $\alpha$ has been observed (Table 5). This reactive environment influences MSCs to secrete anti-inflammatory molecules like IL-10. Moreover, MSCs also release soluble factors (immunosuppressive molecules) like transforming growth factor- $\beta 1$ (TGF- $\beta 1$ ), prostaglandin E2 (PGE2), hepatocyte growth factor (HGF), indoleamine-pyrrole 2,3dioxygenase (IDO), and nitric oxide (NO) [88, 90]. MSCs diminish the inflammation caused by $\mathrm{T}$ cells through secretion of these soluble factors. The soluble factors, TGF- $\beta$, and PGE2, reduce the number of IL-2 receptors and cause a decrease in the proliferation of activated $\mathrm{T}$ cells. Another factor, NO, represses the phosphorylation of signal transducers and transcription of STAT-5 in T cells, leading to the cell cycle arrest. The secretion of IDO by MSCs induces apoptosis of activated $\mathrm{T}$ cells and conversion of tryptophan into kynurenine, this suppresses proliferation of effector $\mathrm{T}$ cells.

In a study, $\mathrm{Li}$ and colleague, have observed that inflammatory cytokines like IL- $1 \alpha$, IL- 6 , TNF- $\alpha$, and IFN- $\gamma$, were reduced in mice when treated with MSCs in H9N2 viral infection [100] and IL- 10 level was elevated (an antiinflammatory cytokine). Studies suggest that Wnt signalling pathway have a pivotal role in regulating the immunomodulatory properties of MSCs. Inhibition of GSK-3 $\beta$, a negative regulator of Wnt signalling, suppresses various cytokines and chemokines involved in the immune response. Lithium chloride $(\mathrm{LiCl})$ is a potent inhibitor of GSK-3 $\beta$, microarray data analysis of lithium stimulated human MSCs have shown significant downregulation in IL-8 and CXCL12 (stromal-derived factor-1) level, which are chemoattractants to neutrophils and T cells respectively. Expression of other chemokines like CXCL1, CXCL20 and CXCL2, which attract 
Table 5 MSCs interact either directly or indirectly through soluble factors to regulate different cytokines

\begin{tabular}{ll}
\hline $\begin{array}{l}\text { Major cytokines released during severe infection } \\
\text { of SARS-CoV-2 }\end{array}$ & Role of MSCs \\
\hline IL-2 & \\
IL-6 & Inhibition of IL-2 via induction of IL-10 and TGF $\beta$ [91]. \\
& Secrete PGE2 (immunomodulator) under high IL-6 level \\
TNF $\alpha$ & [92]. \\
& Inhibit T cells response through NO pathway when TNF $\alpha$ \\
MIP1A (CCL3) & is excess [93]. \\
& Express receptors of chemokine CCL3 to migrate at the site \\
IP10 (CXCL10) & of injury [94]. \\
& Secrete CXCL10 that inhibits T cells via IDO upregulation \\
GM-CSF & {$[95]$.} \\
IL-10 & MSCs recruitment through CXCR-4 at the site of injury \\
& {$[96]$.} \\
IL-8 & High level of TNF $\alpha$ causes induction of IL-10 and TGF $\beta$ \\
IL-1 $\alpha$ & {$[97]$.} \\
IFN $\gamma$ & Suppress IL-8 through Wnt signalling [98]. \\
& Downregulate IL-1 $\alpha$ through Wnt signalling [98]. \\
& Repress T cell response under the influence of IFN $\gamma$, which \\
& induces IDO [99].
\end{tabular}

lymphocytes, neutrophils, and monocytes, was also reduced upon $\mathrm{LiCl}$ priming. Apart from this, repression in inflammatory cytokines like IL- 6 and IL-1a has also been observed with $\mathrm{LiCl}$ treatment. These results suggest a role of $\mathrm{LiCl}$ in MSCs mediated hypoimmunomoduation [98] (Table 5).

Innate immunity is the first line of defence against any kind of infection. MSCs also regulate the innate immune response. Macrophages are the main players in the innate immunity. Engulfment and removal of foreign particles or defective (infected) cells is the main objective of macrophage. Upon interaction with MSCs, macrophages polarize to M2 macrophages (anti-inflammatory). Similarly, upon activation with pro-inflammatory cytokines like TNF- $\alpha$, MSCs elevate the level of cyclooxygenase 2 (COX2), IDO, IL-6 and PGE2, resulting in monocytes (M0) polarization towards $\mathrm{M} 2$ macrophages. Further, M2 macrophage produces IL-10 (antiinflammatory) to maintain homeostasis. However, when the level of IFN- $\gamma$ and TNF- $\alpha$ are low, MSCs polarize the M2 to M1 macrophage that produces IFN- $\gamma$ and TNF- $\alpha$ to stimulate $\mathrm{T}$ cells in a feedback loop manner. Due to these attributes, MSCs may have beneficial effects in attenuating the cytokine storm by secreting powerful anti-inflammatory factors and halt the excessive immune response, while restoring the immune response in the absence of inflammatory environment $[4,5]$. Under the influence of IL-10 and TGF $\beta$, M2 macrophage exhibits enhanced production of human leucocyte antigen (HLA-G5) in MSCs, thereby promoting production and proliferation of $\mathrm{T}_{\text {reg }}$ cells [101]. $\mathrm{T}_{\text {reg }}$ cells are the subpopulation of $\mathrm{T}$ cells that have immune-suppressive properties.

Apart from this, MSCs also function as antigen-presenting cells and express MHC-II complex (major histocompatibility complex class- II) [102]. During antigen presentation, the level of IFN- $\gamma$ increases leading to a subdued expression of MHC-II on MSCs, as a consequence MSCs revert back to an immunosuppressive phenotype and prevent prolonged inflammation [102, 103]. Many studies suggest that culture system has direct cell-cell contact which is another factor involved in the immunomodulatory effects of MSCs. It has been observed that BM-MSCs inhibit proliferation of $\mathrm{T}$ cells whereas they promote proliferation of $\mathrm{T}_{\text {reg }}$ cells in a contactdependent manner [104]. This study is substantiated by other studies in which direct contact between MSCs population and $\mathrm{T}$ cell population is shown to be required for $\mathrm{T}_{\text {reg }}$ induction [105]. Besides the role of IFN- $\gamma$ in immunomodulation, it also upregulates cell adhesion molecules like vascular cell adhesion molecule-1, galectin-1, PD-L1 and CD274. These molecules support cell-cell contact and immunomodulation indicating cellular contact can be one of the mechanisms for immune regulation [88].

\section{Antimicrobial Potential of MSCs}

During pathogenic infection, MSCs constitutively express some AMPs, which exert a powerful antimicrobial effect through a direct-indirect mechanism and immunostimulation [106, 107]. The AMPs are endogenous, positively charged peptides that build a first-line defence to protect a host from various viral infections [108]. The molecular targets of human AMPs are both extracellular and intracellular, as a result, they disrupt membrane integrity, inhibit DNA, RNA and protein synthesis. In recent studies, it was found that MSCs constitutively express different types of AMPs viz. human $\beta$-defensin, 
(hBD), hepcidin and cathelicidin LL-37. Among all the AMPs, hBD and cathelicidin LL-37 are well studied for their antimicrobial role.

$\beta$-Defensin is a cysteine-rich protein consisting of 18 to 145 amino acid, assists to build an immune shield against pathogenic infection. $\beta$-Defensins like hBD-1, hBD-2, and hBD-3 are secreted by MSCs, many epithelial cells, and granulocytes $[109,110]$. The curative role of defensin is well documented in various viral diseases such as HIV, influenza A virus (IAV), human adenovirus (HAdV), severe acute respiratory syndrome coronavirus (SARSC), papillomavirus (HPV), respiratory syncytial virus (RSV), and herpes simplex virus (HSV). It affects viruses by blocking multiple steps in viral cycle like viral entry and viral trafficking within host cells, subsequently triggering immune system against the viral infection by augmenting and recruiting the immune cells like T-cells, macrophage and dendritic cells in tissue [111, 112]. It also inhibits apoptosis process by suppressing the cascape enzyme signalling around the site of infection. Another peptide, LL-37, is encoded by a human cathelicidin antimicrobial peptide gene (CAMP). This peptide has antiviral properties against a wide variety of virus-like HIV-1, IAV, RSV, rhinovirus (HRV), hepatitis $C$ virus (HCV) $[113,114]$. It works by inhibiting the replication and inflammation at the site of action. Recent studies also suggested that these AMPs also obstruct ARDS and facilitate bacterial clearance during MSCs treatment $[115,116]$.

\section{Complications of MSCs Therapy in Clinical Trials}

In the past decade, scientists have shown interest in MSCs based therapies due to their potential use in autologous transplantation. A large number of clinical trials using MSCs are either accomplished or under examination. These studies have explored immunomodulatory and paracrine effects of these cells including secretion of extracellular vesicles, regulatory miRNA, and multiple bioactive proteins. Despite the beneficial effects of MSCs, there are potential risks associated with their use that should be considered before starting MSCs based therapies. The safety and efficacy of transplanted MSCs in the attenuation of inflammatory lung diseases seem to be reasonably proven in experimental models. However, results obtained in already conducted clinical trials pointed at several challenges which have to be addressed before MSCs will be routinely used in clinical settings. For example, bone marrow (BM) MSCs have putative profibrogenic potential, their transplantation have been shown to cause liver fibrosis [117]. Some studies also report issues like tumour growth in a colon cancer model, breast cancer, colorectal cancer, and ovarian, prostate, lung, and gastric carcinoma. MSCs share many features with cancer stem cells (CSCs) like high rate of proliferation, high viability, suppressing antitumor immunity and resistance to apoptosis. Moreover, they also stimulate angiogenesis through secretion of proangiogenic factors, viz. VEGF, HGF, platelet-derived growth factor, angiopoietin-1, and placental growth factor. Therefore therapies utilizing MSCs should require long-term follow-up of patient to observe tumour-inducing effects of MSCs [118-120]. According to a clinical trial performed by Ning and its colleague, patients who received hematopoietic stem cell (HSC) and MSCs transplantation (isolated from bone marrow) had a higher probability of severe infection including interstitial pneumonia and/or fungal infection as compared to the control group not receiving MSCs $[119,121]$. A similar study by Muroi and

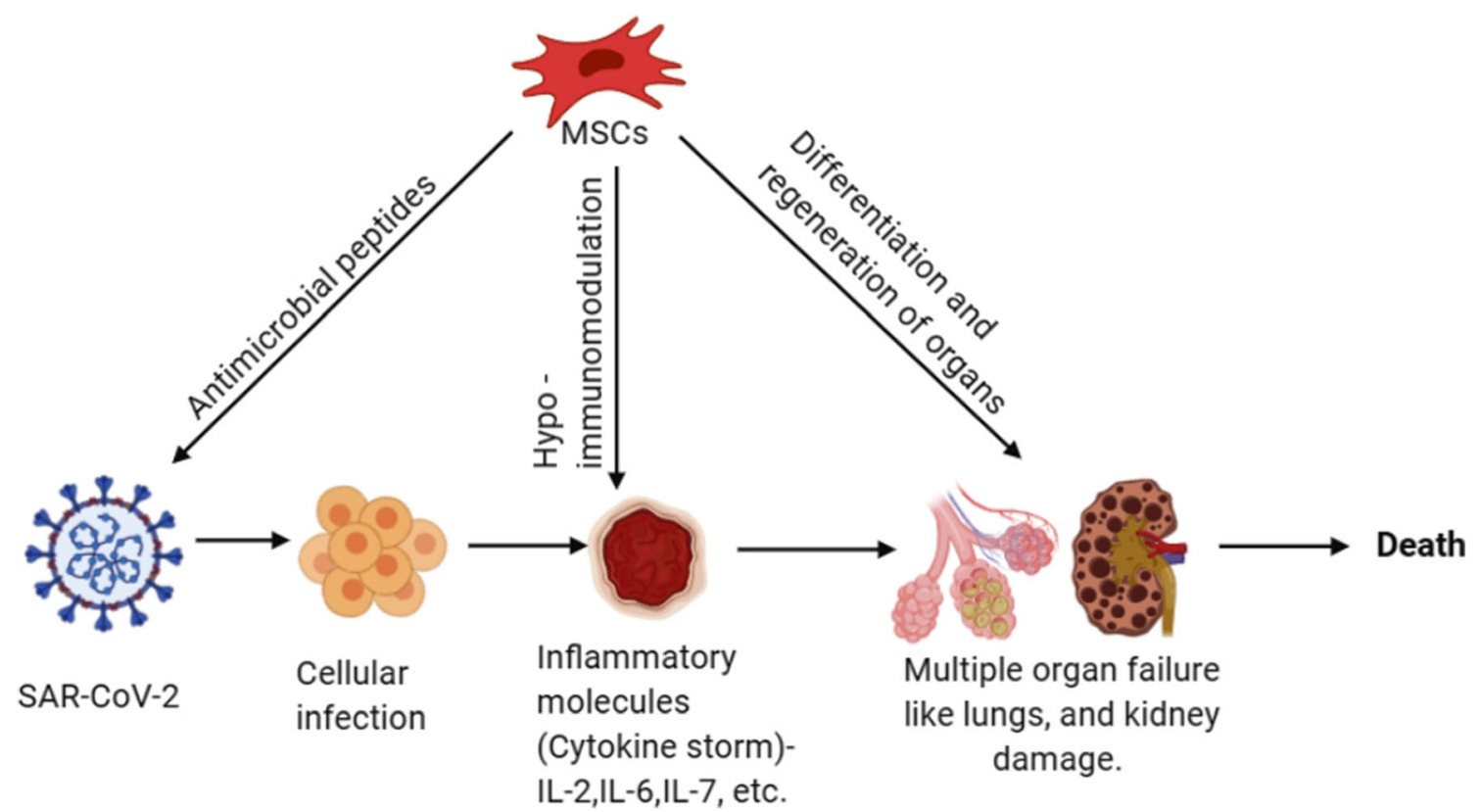

Fig. 4 MSCs inhibiting SARS-CoV-2 infection at various stages 
coworkers showed that during phase II/III clinical trials BMMSCs failed to protect patients from chronic graft-versus-host disease (GvHD) [122]. Multiple studies are performed for evaluating effects of MSCs administration in various neurological disorders, a clinical trial showed the absence of salutary effects after MSCs transplantation. As per a study by Karussis and coworkers, administration of BM-MSCs in patients suffering from amyotrophic lateral sclerosis (ALS), did not lead to any positive effect [123]. The complications observed during MSCs treatment suggested that the regenerative potential of these cells may not be as effective as previously considered. Several exogenous factors interfere with both biological and therapeutic abilities of MSCs. These complications should be considered pragmatically by the scientific community before application of MSCs in COVID-19 and other pathologies.

\section{Conclusion}

The severity of COVID-19 pandemic is increasing rapidly, resulting in a serious healthcare crisis all over the globe. Still, there is no tested method for its cure, therefore a better understanding of this disease is need of the hour. This review presents a detailed description of the genomic organization structure, replication mechanism, and transmission. The roles of drugs and therapies inhibiting viral infection have been described further. During replication in humans, SARSCoV-2 hyperstimulates the immune system to secrete proinflammatory cytokines which cause serious health issues such as pneumonia and ARDS and in severe cases leading to respiratory and multiple organ failure. The pre-clinical and clinical trials suggest that MSCs have immunomodulatory, anti-inflammatory and antimicrobial properties that impede the hyperimmune response, therefore infusion of MSCs in the infected patient is likely to play a key role in encountering the cytokines storm (Fig. 4). During intravenous infusion, most of the MSCs get accumulated in lungs, which is the most affected organ during SARS-CoV-2 infection. Hence, by employing MSCs alone or in combination with other discussed antiviral approaches can make an ideal therapy for treating critically ill patients under the standard protocols of the World Health Organisation (WHO). Nevertheless, no MSCs based therapy is approved for COVID-19 treatment likely due to post-MSCs transplantation complications that can be reduced with experience being obtained during clinical trials.

Acknowledgements We thank Director, INMAS, for his continuous support. This work was funded by the Defence Research Development Organisation, India, project no. S\&T/18-19/INM-323. Images are created with BioRender.com.
Authors' Contributions All authors participated equally in designing the study, drafting, writing, editing the manuscript, and approving it for submission.

\section{Compliance with Ethical Standards}

Conflict of Interest We have no conflicts of interest.

Research Involving Human Participants and/or Animals Not applicable.

Informed Consent Not applicable.

\section{References}

1. Banerjee, A., Kulcsar, K., Misra, V., Frieman, M., \& Mossman, K. (2019). Bats and coronaviruses. Viruses, 11(1), 7-9. https://doi. org/10.3390/v11010041.

2. WHO | Summary of probable SARS cases with onset of illness from 1 November 2002 to 31 July 2003. (2015). WHO.

3. WHO | Middle East respiratory syndrome coronavirus (MERSCoV). (2020). WHO.

4. Leng, Z., Zhu, R., Hou, W., Feng, Y., Yang, Y., Han, Q., ... Zhao, R. C. (2020). Transplantation of ACE2- Mesenchymal Stem Cells Improves the Outcome of Patients with COVID-19 Pneumonia. Aging and disease, 11(2), 216. https://doi.org/10.14336/ad.2020. 0228

5. Bari, E., Ferrarotti, I., Saracino, L., Perteghella, S., Torre, M. L., \& Corsico, A. G. (2020). Mesenchymal Stromal Cell Secretome for Severe COVID-19 Infections: Premises for the Therapeutic Use. Cells, 9(4), 5-10. https://doi.org/10.3390/cells9040924.

6. Shereen, M. A., Khan, S., Kazmi, A., Bashir, N., \& Siddique, R. (2020). COVID-19 infection: Origin, transmission, and characteristics of human coronaviruses. Journal of Advanced Research, 24, 91-98. https://doi.org/10.1016/j.jare.2020.03.005.

7. Zhang, Y. Z., \& Holmes, E. C. (2020). A Genomic Perspective on the Origin and Emergence of SARS-CoV-2. Cell, 181(2), 223227. https://doi.org/10.1016/j.cell.2020.03.035.

8. Worldometer. (2020). Coronavirus Cases. Worldometer. https:// doi.org/10.1101/2020.01.23.20018549V2

9. van Doremalen, N., et al. (n.d.). Aerosol and surface stability of HCoV-19 (SARS-CoV-2) compared to SARS-CoV-1. The New England Journal of Medicine. https://doi.org/10.1056/ NEJMc2004973.

10. Thiel, V., Ivanov, K. A., Putics, Á., Hertzig, T., Schelle, B., Bayer, S., ... Ziebuhr, J. (2003). Mechanisms and enzymes involved in SARS coronavirus genome expression. Journal of General Virology. https://doi.org/10.1099/vir.0.19424-0

11. Wu, F., Zhao, S., Yu, B., Chen, Y. M., Wang, W., Song, Z. G., et al. (2020). A new coronavirus associated with human respiratory disease in China. Nature, 579(7798), 265-269. https://doi. org/10.1038/s41586-020-2008-3.

12. Mielech, A. M., Kilianski, A., Baez-Santos, Y. M., Mesecar, A. D., \& Baker, S. C. (2014). MERS-CoV papain-like protease has deISGylating and deubiquitinating activities. Virology, 450-451, 64-70. https://doi.org/10.1016/j.virol.2013.11.040

13. Mousavizadeh, L., \& Ghasemi, S. (2020). Genotype and phenotype of COVID-19: Their roles in pathogenesis. Journal of Microbiology, Immunology and Infection, (xxxx), 0-4. https:// doi.org/10.1016/j.jmii.2020.03.022

14. Walls, A. C., Park, Y.-J., Tortorici, M. A., Wall, A., Mcguire, A. T., \& Correspondence, D. V. (2020). Structure, Function, and 
Antigenicity of the SARS-CoV-2 Spike Glycoprotein. https://doi. org/10.1016/j.cell.2020.02.058

15. Álvarez, E., DeDiego, M. L., Nieto-Torres, J. L., JiménezGuardeño, J. M., Marcos-Villar, L., \& Enjuanes, L. (2010). The envelope protein of severe acute respiratory syndrome coronavirus interacts with the non-structural protein 3 and is ubiquitinated. Virology, 402(2), 281-291. https://doi.org/10.1016/j.virol.2010. 03.015.

16. Pervushin, K., Tan, E., Parthasarathy, K., Lin, X., Jiang, F. L., Yu, D., ... Torres, J. (2009). Structure and inhibition of the SARS coronavirus envelope protein ion channel. PLoS Pathogens, 5(7). https://doi.org/10.1371/journal.ppat.1000511

17. Schoeman, D., \& Fielding, B. C. (2019). Coronavirus envelope protein: Current knowledge. Virology Journal. BioMed Central Ltd. https://doi.org/10.1186/s12985-019-1182-0

18. Luo, C., Luo, H., Zheng, S., Gui, C., Yue, L., Yu, C., ... Jiang, H. (2004). Nucleocapsid protein of SARS coronavirus tightly binds to human cyclophilin A. Biochemical and Biophysical Research Communications, 321(3), 557-565. https://doi.org/10.1016/j. bbrc.2004.07.003

19. Neuman, B. W., Kiss, G., Kunding, A. H., Bhella, D., Baksh, M. F., Connelly, S., ... Buchmeier, M. J. (2011). A structural analysis of M protein in coronavirus assembly and morphology. Journal of Structural Biology, 174(1), 11-22. https://doi.org/10.1016/j.jsb. 2010.11.021

20. Anand, K., Ziebuhr, J., Wadhwani, P., Mesters, J. R., \& Hilgenfeld, R. (2003). Coronavirus main proteinase (3CLpro) Structure: Basis for design of anti-SARS drugs. Science, 300(5626), 1763-1767. https://doi.org/10.1126/science.1085658.

21. Wang, Q., Wu, J., Wang, H., Gao, Y., Liu, Q., Mu, A., ... Rao, Z. (2020). Structural Basis for RNA Replication by the SARS-CoV2 Polymerase. Cell, 182, 417-428. https://doi.org/10.1016/j.cell. 2020.05 .034

22. Khan, F. A., Asif, M., Ahmad, A., \& Aljuaid, H. (2020). MODS AND SIRS. Sustainable Cities and Society, 102018. https://doi. org/10.1016/j.scs.2020.102018

23. Coronavirus Age, Sex, Demographics (COVID-19) Worldometer. (n.d.). Retrieved July 11, 2020, from https:// www.worldometers.info/coronavirus/coronavirus-age-sexdemographics/

24. Verity, R., Okell, L. C., Dorigatti, I., Winskill, P., Whittaker, C., Imai, N., ... Ferguson, N. M. (2020). Estimates of the severity of coronavirus disease 2019: a model-based analysis. The Lancet Infectious Diseases, 20(6), 669-677. https://doi.org/10.1016/ S1473-3099(20)30243-7

25. Liu, Y., Mao, B., Liang, S., Yang, J. W., Lu, H. W., Chai, Y. H., ... Xu, J. F. (2020). Association between age and clinical characteristics and outcomes of COVID-19. The European respiratory journal. NLM (Medline). https://doi.org/10.1183/13993003. 01112-2020

26. Mallapaty, S. (2020). How deadly is the coronavirus? Scientists are close to an answer. Nature. NLM (Medline). https://doi.org/ 10.1038/d41586-020-01738-2

27. Zhang, C., Wu, Z., Li, J.-W., Zhao, H., \& Wang, G.-Q. (2020). The cytokine release syndrome (CRS) of severe COVID-19 and Interleukin-6 receptor (IL-6R) antagonist Tocilizumab may be the key to reduce the mortality. International Journal of Antimicrobial Agents, 105954. https://doi.org/10.1016/j.ijantimicag.2020. 105954

28. Prompetchara, E., Ketloy, C., \& Palaga, T. (2020). Immune responses in COVID-19 and potential vaccines: Lessons learned from SARS and MERS epidemic. Asian Pacific journal of allergy and immunology. NLM (Medline). https://doi.org/10.12932/AP200220-0772

29. Liu, W., Fontanet, A., Zhang, P., Zhan, L., Xin, Z., Baril, L., ... Cao, W. (2006). Two-Year Prospective Study of the Humoral
Immune Response of Patients with Severe Acute Respiratory Syndrome. The Journal of Infectious Diseases, 193(6), 792-795. https://doi.org/10.1086/500469

30. Huang, C., Wang, Y., Li, X., Ren, L., Zhao, J., Hu, Y., ... Cao, B. (2020). Clinical features of patients infected with 2019 novel coronavirus in Wuhan, China. The Lancet, 395(10223), 497-506. https://doi.org/10.1016/S0140-6736(20)30183-5

31. Zhu, N., Zhang, D., Wang, W., Li, X., Yang, B., Song, J., ... Tan, W. (2020). A novel coronavirus from patients with pneumonia in China, 2019. New England Journal of Medicine, 382(8), 727-733. https://doi.org/10.1056/NEJMoa2001017

32. Hoffmann, M., Kleine-Weber, H., Schroeder, S., Krüger, N., Herrler, T., Erichsen, S., ... Pöhlmann, S. (2020). SARS-CoV-2 Cell Entry Depends on ACE2 and TMPRSS2 and Is Blocked by a Clinically Proven Protease Inhibitor. Cell, 181(2), 271-280.e8. https://doi.org/10.1016/j.cell.2020.02.052

33. Glowacka, I., Bertram, S., Muller, M. A., Allen, P., Soilleux, E., Pfefferle, S., ... Pohlmann, S. (2011). Evidence that TMPRSS2 Activates the Severe Acute Respiratory Syndrome Coronavirus Spike Protein for Membrane Fusion and Reduces Viral Control by the Humoral Immune Response. Journal of Virology, 85(9), 4122-4134. https://doi.org/10.1128/jvi.02232-10

34. Imai, Y., Kuba, K., Rao, S., Huan, Y., Guo, F., Guan, B., ... Penninger, J. M. (2005). Angiotensin-converting enzyme 2 protects from severe acute lung failure. Nature, 436(7047), 112-116. https://doi.org/10.1038/nature03712

35. Stadler, K., Ha, H. R., Ciminale, V., Spirli, C., Saletti, G., Schiavon, M., ... Baritussio, A. (2008). Amiodarone alters late endosomes and inhibits SARS coronavirus infection at a postendosomal level. American Journal of Respiratory Cell and Molecular Biology, 39(2), 142-149. https://doi.org/10.1165/ rcmb.2007-02170C

36. Wilson, L., Gage, P., \& Ewart, G. (2006). Hexamethylene amiloride blocks $\mathrm{E}$ protein ion channels and inhibits coronavirus replication. Virology, 353(2), 294-306. https://doi.org/10.1016/j. virol.2006.05.028.

37. Li, C., Zhu, X., Ji, X., Quanquin, N., Deng, Y. Q., Tian, M., ... Cheng, G. (2017). Chloroquine, a FDA-approved Drug, Prevents Zika Virus Infection and its Associated Congenital Microcephaly in Mice. EBioMedicine, 24, 189-194. https://doi.org/10.1016/j. ebiom.2017.09.034

38. Gao, J., Tian, Z., \& Yang, X. (2020). Breakthrough: Chloroquine phosphate has shown apparent efficacy in treatment of COVID-19 associated pneumonia in clinical studies. BioScience Trends. International Advancement Center for Medicine and Health Research Co., Ltd. https://doi.org/10.5582/BST.2020.01047

39. Warren, T. K., Jordan, R., Lo, M. K., Ray, A. S., Mackman, R. L., Soloveva, V., ... Bavari, S. (2016). Therapeutic efficacy of the small molecule GS-5734 against Ebola virus in rhesus monkeys. Nature, 531(7594), 381-385. https://doi.org/10.1038/ nature 17180

40. Sheahan, T. P., Sims, A. C., Graham, R. L., Menachery, V. D., Gralinski, L. E., Case, J. B., ... Baric, R. S. (2017). Broadspectrum antiviral GS-5734 inhibits both epidemic and zoonotic coronaviruses. Science Translational Medicine, 9(396). https:// doi.org/10.1126/scitranslmed.aal3653

41. de Wit, E., Feldmann, F., Cronin, J., Jordan, R., Okumura, A., Thomas, T., ... Feldmann, H. (2020). Prophylactic and therapeutic remdesivir (GS-5734) treatment in the rhesus macaque model of MERS-CoV infection. Proceedings of the National Academy of Sciences of the United States of America, 117(12), 6771-6776. https://doi.org/10.1073/pnas.1922083117

42. Shippey, E. A., Wagler, V. D., \& Collamer, A. N. (2018). Hydroxychloroquine: An old drug with new relevance. Cleveland Clinic Journal of Medicine, 85(6), 459-467. https:// doi.org/10.3949/ccjm.85a.17034. 
43. Devaux, C. A., Rolain, J.-M., Colson, P., \& Raoult, D. (2020). New insights on the antiviral effects of chloroquine against coronavirus: what to expect for COVID-19? International Journal of Antimicrobial Agents, 105938. https://doi.org/10.1016/j. ijantimicag.2020.105938

44. Hull, M. W., \& Montaner, J. S. G. (2011). Ritonavir-boosted protease inhibitors in HIV therapy. Annals of Medicine, 43(5), 375-388. https://doi.org/10.3109/07853890.2011.572905.

45. Das, A., \& Hosur, M. V. (2010). X-Ray Structure of HIV-1 Protease Tethered Dimer Complexed to Ritonavir. Protein \& Peptide Letters, 14(6), 565-568. https://doi.org/10.2174/ 092986607780989930.

46. Genovese, M. C., Kremer, J., Zamani, O., Ludivico, C., Krogulec, M., Xie, L., ... Smolen, J. S. (2016). Baricitinib in patients with refractory rheumatoid arthritis. New England Journal of Medicine, 374(13), 1243-1252. https://doi.org/10.1056/NEJMoa1507247

47. Kuriya, B., Cohen, M. D., \& Keystone, E. (2017). Baricitinib in rheumatoid arthritis: evidence-to-date and clinical potential. Therapeutic Advances in Musculoskeletal Disease. SAGE Publications Ltd. https://doi.org/10.1177/1759720X16687481

48. Han Ni, S. M. K. T. M. A. H. (2013). Oral Janus Kinase Inhibitor for the Treatment of Rheumatoid Arthritis: Tofacitinib - PubMed. Retrieved April 23, 2020, from https://pubmed.ncbi.nlm.nih.gov/ 23970975/

49. O’Shea, J. J., Kontzias, A., Yamaoka, K., Tanaka, Y., \& Laurence, A. (2013). Janus kinase inhibitors in autoimmune diseases. Annals of the Rheumatic Diseases, 72(SUPPL. 2). https://doi.org/10. 1136/annrheumdis-2012-202576.

50. Baden, L. R., \& Rubin, E. J. (2020). Covid-19 - The Search for Effective Therapy. The New England Journal of Medicine. https:// doi.org/10.1056/nejme2005477.

51. Siddiqi, H. K., \& Mehra, M. R. (2020). COVID-19 Illness in Native and Immunosuppressed States: A Clinical-Therapeutic Staging Proposal. The Journal of Heart and Lung Transplantation. https://doi.org/10.1016/j.healun.2020.03.012.

52. Louie, J. K., Yang, S., Acosta, M., Yen, C., Samuel, M. C., Schechter, R., ... Uyeki, T. M. (2009). Treatment With Neuraminidase Inhibitors for Critically Ill Patients With Influenza A (H1N1) pdm09. https://doi.org/10.1093/cid/cis636

53. Sundquist, W. I., \& Kräusslich, H. G. (2012). HIV-1 assembly, budding, and maturation. Cold Spring Harbor Perspectives in Medicine. Cold Spring Harbor Laboratory Press. https://doi.org/ 10.1101/cshperspect.a006924

54. De Clercq, E. (2009). Anti-HIV drugs: 25 compounds approved within 25 years after the discovery of HIV. International Journal of Antimicrobial Agents. Elsevier. https://doi.org/10.1016/j. ijantimicag.2008.10.010

55. Kumar, G. N., Jayanti, V., Lee, R. D., Whittern, D. N., Uchic, J., Thomas, S., ... Denissen, J. F. (1999). In Vitro Metabolism of the HIV-1 Protease Inhibitor ABT-378: Species Comparison and Metabolite Identification. Drug Metabolism and Disposition, 27(1).

56. Villain-Guillot, P., Bastide, L., Gualtieri, M., \& Leonetti, J. P. (2007). Progress in targeting bacterial transcription. Drug Discovery Today. Drug Discov Today. https://doi.org/10.1016/j. drudis.2007.01.005

57. White, R. J., Lancini, G. C., \& Silvestri, L. G. (1971). Mechanism of action of rifampin on Mycobacterium smegmatis. Journal of Bacteriology, 108(2), 737-741. https://doi.org/10.1128/jb.108.2. 737-741.1971.

58. Tupin, A., Gualtieri, M., Roquet-Banères, F., Morichaud, Z., Brodolin, K., \& Leonetti, J. P. (2010). Resistance to rifampicin: At the crossroads between ecological, genomic and medical concerns. International Journal of Antimicrobial Agents. https://doi. org/10.1016/j.ijantimicag.2009.12.017
59. Campbell, E. A., Korzheva, N., Mustaev, A., Murakami, K., Nair, S., Goldfarb, A., \& Darst, S. A. (2001). Structural mechanism for rifampicin inhibition of bacterial RNA polymerase. Cell, 104(6), 901-912. https://doi.org/10.1016/S0092-8674(01)00286-0.

60. Tremblay, C. L. (2008). Combating HIV resistance - Focus on darunavir. Therapeutics and Clinical Risk Management. https:// doi.org/10.2147/TCRM.S1709

61. De Meyer, S., Azijn, H., Surleraux, D., Jochmans, D., Tahri, A., Pauwels, R., ... De Béthune, M. P. (2005). TMC114, a novel human immunodeficiency virus type 1 protease inhibitor active against protease inhibitor-resistant viruses, including a broad range of clinical isolates. Antimicrobial Agents and Chemotherapy, 49(6), 2314-2321. https://doi.org/10.1128/AAC. 49.6.2314-2321.2005

62. Hayden, F. G., \& Shindo, N. (2019). Influenza virus polymerase inhibitors in clinical development. Current Opinion in Infectious Diseases. Lippincott Williams and Wilkins. https://doi.org/10. 1097/QCO.0000000000000532

63. Furuta, Y., Komeno, T., \& Nakamura, T. (2017). Favipiravir (T-705), a broad spectrum inhibitor of viral RNA polymerase. Proceedings of the Japan Academy Series B: Physical and Biological Sciences. Japan Academy. https://doi.org/10.2183/ pjab.93.027

64. Venkataraman, S., Prasad, B. V. L. S., \& Selvarajan, R. (2018). RNA dependent RNA polymerases: Insights from structure, function and evolution. Viruses. MDPI AG. https://doi.org/10.3390/ v10020076

65. Russia approves first drug for Covid-19 treatment - Public Radio of Armenia. (n.d.). Retrieved June 1, 2020, from https://en. armradio.am/2020/05/30/russia-approves-first-drug-for-covid-19treatment/

66. Westover, J. B., Mathis, A., Taylor, R., Wandersee, L., Bailey, K. W., Sefing, E. J., ... Gowen, B. B. (2018). Galidesivir limits Rift Valley fever virus infection and disease in Syrian golden hamsters. Antiviral Research, 156, 38-45. https://doi.org/10.1016/j. antiviral.2018.05.013

67. Lu, H. (2020). Drug treatment options for the 2019-new coronavirus (2019-nCoV). Bioscience Trends, 14(1). https://doi.org/10. 5582/BST.2020.01020.

68. Blaising, J., Polyak, S. J., \& Pécheur, E. I. (2014). Arbidol as a broad-spectrum antiviral: An update. Antiviral Research. Elsevier. https://doi.org/10.1016/j.antiviral.2014.04.006

69. Deng, P., Zhong, D., Yu, K., Zhang, Y., Wang, T., \& Chen, X. (2013). Pharmacokinetics, metabolism, and excretion of the antiviral drug arbidol in humans. Antimicrobial Agents and Chemotherapy, 57(4), 1743-1755. https://doi.org/10.1128/AAC. 02282-12.

70. Wang, Z., Chen, X., Lu, Y., Chen, F., \& Zhang, W. (2020). Clinical characteristics and therapeutic procedure for four cases with 2019 novel coronavirus pneumonia receiving combined Chinese and Western medicine treatment. Bioscience Trends, 14(1). https://doi.org/10.5582/BST.2020.01030.

71. Sanchez-Ramos, J., Song, S., Cardozo-Pelaez, F., Hazzi, C., Stedeford, T., Willing, A., ... Sanberg, P. R. (2000). Adult bone marrow stromal cells differentiate into neural cells in vitro. Experimental Neurology, 164(2), 247-256. https://doi.org/10. 1006/exnr.2000.7389

72. Ullah, I., Subbarao, R. B., \& Rho, G. J. (2015). Human mesenchymal stem cells - Current trends and future prospective. Bioscience Reports, 35. https://doi.org/10.1042/BSR20150025

73. Balamurugan, K., \& Said, H. M. (2006). Role of reduced folate carrier in intestinal folate uptake. American Journal of Physiology - Cell Physiology, 291(1). https://doi.org/10.1152/ajpcell.00594. 2005.

74. Carapagnoli, C., Fisk, N. M., Kumar, S., Bellantuono, L., Bennett, P. R., \& Roberts, I. A. G. (2000). Identification of mesenchymal 
stem cells in human first trimester fetal blood, liver and bone marrow. Blood, 96(11 PART I), 2396-2402.

75. Jones, E. A., Kinsey, S. E., English, A., Jones, R. A., Straszynski, L., Meredith, D. M., ... McGonagle, D. (2002). Isolation and characterization of bone marrow multipotential mesenchymal progenitor cells. Arthritis and Rheumatism, 46(12), 3349-3360. https://doi.org/10.1002/art.10696

76. Zhang, Y., Li, C., Jiang, X., Zhang, S., Wu, Y., Liu, B., ... Mao, N. (2004). Human placenta-derived mesenchymal progenitor cells support culture expansion of long-term culture-initiating cells from cord blood CD34+ cells. Experimental Hematology, 32(7), 657-664. https://doi.org/10.1016/j.exphem.2004.04.001

77. Gang, E. J. (2004). S tem C Skeletal Myogenic Differentiation of Mesenchymal Stem Cells Isolated from Human Umbilical Cord Bloodells. Stem Cells, 22, 617-624.

78. Dominici, M., Le Blanc, K., Mueller, I., Slaper-Cortenbach, I., Marini, F. C., Krause, D. S., ... Horwitz, E. M. (2006). Minimal criteria for defining multipotent mesenchymal stromal cells. The International Society for Cellular Therapy position statement. Cytotherapy, 8(4), 315-317. https://doi.org/10.1080/ 14653240600855905

79. Horwitz, E. M., Le Blanc, K., Dominici, M., Mueller, I., SlaperCortenbach, I., Marini, F. C., ... Keating, A. (2005). Clarification of the nomenclature for MSC: The International Society for Cellular Therapy position statement. Cytotherapy, 7(5), 393395. https://doi.org/10.1080/14653240500319234

80. Liang, B., Chen, J., Li, T., Wu, H., Yang, W., Li, Y., ... Hu, M. (2020). Clinical remission of a critically ill COVID-19 patient treated by human umbilical cord mesenchymal stem cells. ChinaXiv. https://doi.org/10.3969/j.issn.2095-4344.2012.49.011

81. Shetty, A. K. (2020). Mesenchymal stem cell infusion shows promise for combating coronavirus (COVID-19)-induced pneumonia. Aging and Disease, 11(2), 462-464. https://doi.org/10. 14336/AD.2020.0301.

82. Atluri, S., Manchikanti, L., \& Hirsch, J. A. (2020). Expanded Umbilical Cord Mesenchymal Stem Cells (UC-MSCs) as a Therapeutic Strategy in Managing Critically Ill COVID-19 Patients: The Case for Compassionate Use. Pain Physician, 23(2), E71-E83.

83. Basiri, A., Pazhouhnia, Z., Beheshtizadeh, N., Hoseinpour, M., Saghazadeh, A., \& Rezaei, N. (2020). Regenerative Medicine in COVID-19 Treatment: Real Opportunities and Range of Promises. Stem Cell Reviews and Reports. https://doi.org/10. 1007/s12015-020-09994-5.

84. Golchin, A., Seyedjafari, E., \& Ardeshirylajimi, A. (2020). Mesenchymal Stem Cell Therapy for COVID-19: Present or Future. Stem Cell Reviews and Reports. https://doi.org/10.1007/ s12015-020-09973-w.

85. Home - ClinicalTrials.gov. (n.d.). Retrieved July 17, 2020, from https://clinicaltrials.gov/

86. Raza, S. S., Seth, P., \& Khan, M. A. (2020). 'Primed' Mesenchymal Stem Cells: a Potential Novel Therapeutic for COVID19 Patients. Stem Cell Reviews and Reports. https://doi. org/10.1007/s12015-020-09999-0.

87. de Witte, S. F. H., Luk, F., Sierra Parraga, J. M., Gargesha, M., Merino, A., Korevaar, S. S., ... Hoogduijn, M. J. (2018). Immunomodulation By Therapeutic Mesenchymal Stromal Cells (MSC) Is Triggered Through Phagocytosis of MSC By Monocytic Cells. Stem Cells, 36(4), 602-615. https://doi.org/10.1002/stem. 2779

88. Gao, F., Chiu, S. M., Motan, D. A. L., Zhang, Z., Chen, L., Ji, H. L., ... Lian, Q. (2016). Mesenchymal stem cells and immunomodulation: Current status and future prospects. Cell Death and Disease, 7(1). https://doi.org/10.1038/cddis.2015.327

89. Yagi, H., Soto-Gutierrez, A., Parekkadan, B., Kitagawa, Y., Tompkins, R. G., Kobayashi, N., \& Yarmush, M. L. (2010).
Mesenchymal stem cells: Mechanisms of immunomodulation and homing. Cell Transplantation, 19(6-7), 667-679. https:// doi.org/10.3727/096368910X508762.

90. Regmi, S., Pathak, S., Kim, J. O., Yong, C. S., \& Jeong, J. H. (2019). Mesenchymal stem cell therapy for the treatment of inflammatory diseases: Challenges, opportunities, and future perspectives. European Journal of Cell Biology, 98(5-8), 0-1. https://doi.org/10.1016/j.ejcb.2019.04.002

91. Jorgensen, C. (2010). Mesenchymal stem cells immunosuppressive properties: Is it specific to bone marrow-derived cells? Stem Cell Research \& Therapy, 1(2), 15. https://doi.org/10.1186/scrt15.

92. Bouffi, C., Bony, C., Courties, G., Jorgensen, C., \& Noël, D. (2010). IL-6-Dependent PGE2 Secretion by Mesenchymal Stem Cells Inhibits Local Inflammation in Experimental Arthritis. PLoS One, 5(12), e14247. https://doi.org/10.1371/journal.pone. 0014247.

93. Putra, A., Ridwan, F. B., Putridewi, A. I., Kustiyah, A. R., Wirastuti, K., Sadyah, N. A. C., ... Munir, D. (2018). The role of tnf- $\alpha$ induced mscs on suppressive inflammation by increasing $\operatorname{tgf}-\beta$ and il-10. Open Access Macedonian Journal of Medical Sciences, 6(10), 1779-1783. https://doi.org/10.3889/oamjms. 2018.404

94. Takano, T., Li, Y. J., Kukita, A., Yamaza, T., Ayukawa, Y., Moriyama, K., ... Kukita, T. (2014). Mesenchymal stem cells markedly suppress inflammatory bone destruction in rats with adjuvant-induced arthritis. Laboratory Investigation, 94(3), 286296. https://doi.org/10.1038/labinvest.2013.152

95. Podestà, M. A., Remuzzi, G., \& Casiraghi, F. (2019). Mesenchymal stromal cells for transplant tolerance. Frontiers in Immunology. Frontiers Media S.A. https://doi.org/10.3389/ fimmu.2019.01287

96. Kim, J., Kim, N. K., Park, S. R., \& Choi, B. H. (2019). GM-CSF Enhances Mobilization of Bone Marrow Mesenchymal Stem Cells via a CXCR4-Medicated Mechanism. Tissue Engineering and Regenerative Medicine, 16(1), 59-68. https://doi.org/10. 1007/s13770-018-0163-5.

97. Kitani, A., Fuss, I., Nakamura, K., Kumaki, F., Usui, T., \& Strober, W. (2003). Transforming Growth Factor (TGF)- $\beta 1$-producing Regulatory T Cells Induce Smad-mediated Interleukin 10 Secretion That Facilitates Coordinated Immunoregulatory Activity and Amelioration of TGF- $\beta 1$-mediated Fibrosis. Journal of Experimental Medicine, 198(8), 1179-1188. https:// doi.org/10.1084/jem.20030917.

98. Gangenahalli, G., Satija, N., Afrin, F., \& Tripathi, R. P. (2011). High-Throughput Transcriptome Profiling Of Human Mesenchymal Stem Cells Reveals A Role For Wnt/GSK-3 Signaling In Their Hypoimmunomodulation. Nature Precedings, 1-1. https://doi.org/10.1038/npre.2011.5512.1

99. Takeshita, K., Motoike, S., Kajiya, M., Komatsu, N., Takewaki, M., Ouhara, K., ... Kurihara, H. (2017). Xenotransplantation of interferon-gamma-pretreated clumps of a human mesenchymal stem cell/extracellular matrix complex induces mouse calvarial bone regeneration. Stem Cell Research and Therapy, 8(1), 101. https://doi.org/10.1186/s13287-017-0550-1

100. Li, Y., Xu, J., Shi, W., Chen, C., Shao, Y., Zhu, L., ... Han, X. D. (2016). Mesenchymal stromal cell treatment prevents H9N2 avian influenza virus-induced acute lung injury in mice. Stem Cell Research and Therapy, 7(1), 1-11. https://doi.org/10.1186/ s13287-016-0395-z

101. Li, H., Shen, S., Fu, H., Wang, Z., Li, X., Sui, X., ... Guo, Q. (2019). Immunomodulatory functions of mesenchymal stem cells in tissue engineering. Stem Cells International, 2019. https://doi. org/10.1155/2019/9671206

102. Chan, J. L., Tang, K. C., Patel, A. P., Bonilla, L. M., Pierobon, N., Ponzio, N. M., \& Rameshwar, P. (2006). Antigen-presenting property of mesenchymal stem cells occurs during a narrow 
window at low levels of interferon- $\gamma$. Blood, 107(12), 4817-4824. https://doi.org/10.1182/blood-2006-01-0057.

103. Aggarwal, S., \& Pittenger, M. F. (2005). Human mesenchymal stem cells modulate allogeneic immune cell responses. Blood, 105(4), 1815-1822. https://doi.org/10.1182/blood-2004-04-1559.

104. Han, K. H., Ro, H., Hong, J. H., Lee, E. M., Cho, B., Yeom, H. J., et al. (2011). Immunosuppressive mechanisms of embryonic stem cells and mesenchymal stem cells in alloimmune response. Transplant Immunology, 25(1), 7-15. https://doi.org/10.1016/j. trim.2011.05.004.

105. English, K., Ryan, J. M., Tobin, L., Murphy, M. J., Barry, F. P., \& Mahon, B. P. (2009). Cell contact, prostaglandin E2 and transforming growth factor beta 1 play non-redundant roles in human mesenchymal stem cell induction of CD4+ CD25Highforkhead box P3+ regulatory T cells. Clinical and Experimental Immunology, 156(1), 149-160. https://doi.org/10. 1111/j.1365-2249.2009.03874.x.

106. Esfandiyari, R., Halabian, R., Behzadi, E., Sedighian, H., Jafari, R., \& Imani Fooladi, A. A. (2019). Performance evaluation of antimicrobial peptide 11-37 and hepcidin and $\beta$-defensin-2 secreted by mesenchymal stem cells. Heliyon. Elsevier Ltd. https://doi.org/ 10.1016/j.heliyon.2019.e02652

107. Hsieh, I.-N., \& Hartshorn, K. (2016). The Role of Antimicrobial Peptides in Influenza Virus Infection and Their Potential as Antiviral and Immunomodulatory Therapy. Pharmaceuticals, 9(3), 53. https://doi.org/10.3390/ph9030053.

108. Zhang, L. J., \& Gallo, R. L. (2016). Antimicrobial peptides. Current Biology. Cell Press. https://doi.org/10.1016/j.cub.2015. 11.017

109. Kim, J. M. (2014). Antimicrobial Proteins in Intestine and Inflammatory Bowel Diseases. Intestinal Research, 12(1), 20. https://doi.org/10.5217/ir.2014.12.1.20.

110. Sung, D. K., Chang, Y. S., Sung, S. I., Yoo, H. S., Ahn, S. Y., \& Park, W. S. (2016). Antibacterial effect of mesenchymal stem cells against Escherichia coli is mediated by secretion of beta- defensin2 via toll- like receptor 4 signalling. Cellular Microbiology, 18(3), 424-436. https://doi.org/10.1111/cmi.12522.

111. Pachón-Ibáñez, M. E., Smani, Y., Pachón, J., Sánchez-Céspedes, J. (2017). Perspectives for clinical use of engineered human host defense antimicrobial peptides. FEMS Microbiology Reviews, 012, 323-342. https://doi.org/10.1093/femsre/fux012

112. Castañeda-Sánchez, J. I., Domínguez-Martínez, D. A., OlivarEspinosa, N., García-Pérez, B. E., Loroño-Pino, M. A., LunaHerrera, J., Salazar, M. I. (2016). Expression of Antimicrobial Peptides in Human Monocytic Cells and Neutrophils in Response to Dengue Virus Type 2. https://doi.org/10.1159/ 000446282

113. Matsumura, T., Sugiyama, N., Murayama, A., Yamada, N., Shiina, M., Asabe, S., ... Kato, T. (2016). Antimicrobial peptide LL-37 attenuates infection of hepatitis C virus. Hepatology Research, 46(9), 924-932. https://doi.org/10.1111/hepr.12627

114. Currie, S. M., Findlay, E. G., McHugh, B. J., Mackellar, A., Man, T., Macmillan, D., ... Davidson, D. J. (2013). The Human
Cathelicidin LL-37 Has Antiviral Activity against Respiratory Syncytial Virus. PLoS ONE, 8(8), e73659. https://doi.org/10. 1371/journal.pone.0073659

115. Lee, J. W., Krasnodembskaya, A., McKenna, D. H., Song, Y., Abbott, J., \& Matthay, M. A. (2013). Therapeutic effects of human mesenchymal stem cells in ex vivo human lungs injured with live bacteria. American Journal of Respiratory and Critical Care Medicine, 187(7), 751-760. https://doi.org/10.1164/rccm. 201206-0990OC.

116. Alcayaga-Miranda, F., Cuenca, J., \& Khoury, M. (2017). Antimicrobial activity of mesenchymal stem cells: Current status and new perspectives of antimicrobial peptide-based therapies. Frontiers in Immunology. Frontiers Media S.A. https://doi.org/ 10.3389/fimmu.2017.00339

117. Lee, S. H. (2018). The advantages and limitations of mesenchymal stem cells in clinical application for treating human diseases. Osteoporosis and Sarcopenia, 4(4), 150. https://doi.org/10.1016/ j.afos.2018.11.083.

118. Musiak-Wysocka, A., Kot, M., \& Majka, M. (2019). The Pros and Cons of Mesenchymal Stem Cell-Based Therapies. Cell Transplantation, 28(7), 801-812. https://doi.org/10.1177/ 0963689719837897.

119. Lukomska, B., Stanaszek, L., Zuba-Surma, E., Legosz, P., Sarzynska, S., \& Drela, K. (2019). Challenges and Controversies in Human Mesenchymal Stem Cell Therapy. Stem Cells International, 2019. https://doi.org/10.1155/2019/9628536

120. Volarevic, V., Markovic, B. S., Gazdic, M., Volarevic, A., Jovicic, N., Arsenijevic, N., ... Stojkovic, M. (2018). Ethical and safety issues of stem cell-based therapy. International Journal of Medical Sciences. Ivyspring International Publisher. https://doi. org/10.7150/ijms.21666

121. Ning, H., Yang, F., Jiang, M., Hu, L., Feng, K., Zhang, J., ... Chen, H. (2008). The correlation between cotransplantation of mesenchymal stem cells and higher recurrence rate in hematologic malignancy patients: Outcome of a pilot clinical study. Leukemia, 22(3), 593-599. https://doi.org/10.1038/sj.leu.2405090

122. Muroi, K., Miyamura, K., Okada, M., Yamashita, T., Murata, M., Ishikawa, T., ... Ozawa, K. (2016). Bone marrow-derived mesenchymal stem cells (JR-031) for steroid-refractory grade III or IV acute graft-versus-host disease: a phase II/III study. International Journal of Hematology, 103(2), 243-250. https://doi.org/10.1007/ s12185-015-1915-9

123. Karussis, D., Karageorgiou, C., Vaknin-Dembinsky, A., GowdaKurkalli, B., Gomori, J. M., Kassis, I., ... Slavin, S. (2010). Safety and immunological effects of mesenchymal stem cell transplantation in patients with multiple sclerosis and amyotrophic lateral sclerosis. Archives of Neurology, 67(10), 1187-1194. https://doi. org/10.1001/archneurol.2010.248

Publisher's Note Springer Nature remains neutral with regard to jurisdictional claims in published maps and institutional affiliations. 